\title{
Hair-Bundle Links: Genetics as the Gateway to Function
}

\author{
Guy P. Richardson ${ }^{1}$ and Christine Petit ${ }^{2,3}$ \\ ${ }^{1}$ Sussex Neuroscience, School of Life Sciences, University of Sussex, Falmer, Brighton BN1 9QG, \\ United Kingdom \\ ${ }^{2}$ Institut Pasteur, 75724 Paris Cedex 15, France \\ ${ }^{3}$ Collège de France, 75231 Paris Cedex 05, France \\ Correspondence: g.p.richardson@sussex.ac.uk; christine.petit@pasteur.fr
}

Up to five distinct cell-surface specializations interconnect the stereocilia and the kinocilium of the mature hair bundle in some species: kinocilial links, tip links, top connectors, shaft connectors, and ankle links. In developing hair bundles, transient lateral links are prominent. Mutations in genes encoding proteins associated with these links cause Usher deafness/ blindness syndrome or nonsyndromic (isolated) forms of human hereditary deafness, and mice with constitutive or conditional alleles of these genes have provided considerable insight into the molecular composition and function of the different links. We describe the structure of these links and review evidence showing $\mathrm{CDH} 23$ and $\mathrm{PCDH} 15$ are components of the tip, kinocilial, and transient-lateral links, that stereocilin (STRC) and protein tyrosine phosphatase (PTPRQ) are associated with top and shaft connectors, respectively, and that USH2A and ADGRV1 are associated with the ankle links. Whereas tip links are required for mechanoelectrical transduction, all link proteins play key roles in the normal development and/or the maintenance of hair bundle structure and function. Recent crystallographic and single-particle analyses of $\mathrm{PCDH} 15$ and $\mathrm{CDH} 23$ provide insight as to how the structure of tip link may contribute to the elastic element predicted to lie in series with the hair cell's mechanoelectrical transducer channel.

$T^{\mathrm{h}}$ he hair cells of the vertebrate inner ear and those in the lateral line organs of fish, all larval amphibia, and mature aquatic amphibia are polarized epithelial cells that detect sounds, head acceleration, body motion or water flow, and generate electrical signals that are then relayed via the axons of afferent neurons to the central nervous system. The process of mechanoelectrical transduction occurs in the hair bundle, a highly specialized structure that is located at the apical pole of the hair cell. Hair bundles come in a variety of shapes and sizes in different organs and species, and are presumably tailored to the stimulus parameters that each encounters. Nonetheless, all conform, at least during the early stages of their development, to the same basic plan, containing two or more height-ranked rows of actin-packed stereocilia and a single microtubule-based kinocilium. A kinocilium is present in the hair bundles of most organs, but is lost from the hair bundles of the mammalian cochlea during the early

Editors: Guy P. Richardson and Christine Petit

Additional Perspectives on Function and Dysfunction of the Cochlea available at www.perspectivesinmedicine.org

Copyright (C) 2019 Cold Spring Harbor Laboratory Press; all rights reserved; doi: 10.1101/cshperspect.a033142

Cite this article as Cold Spring Harb Perspect Med 2019;9:a033142 


\section{G.P. Richardson and C. Petit}

stages of postnatal development and before the onset of hearing. The stereocilia are modified microvilli and the kinocilium, when present, has the $9+2$ arrangement of microtubule doublets surrounding a pair of central microtubules that is characteristic of motile stereocilia (Flock and Duvall 1965). The kinocilium connects to a basal body, one of a pair of centrioles present at the top of the hair cell soma and flagellar, whiplike movements of hair-cell kinocilia have been described in at least one species, in the semicircular canal organs of the eel (Rüsch and Thurm 1990). These elements of the hair bundle, the kinocilium and the stereocilia, are interconnected by a number of morphologically and molecularly distinct cell surface specializations, which are known as hair-bundle links.
In the hair bundles of some organs up to five types of link have been described; kinocilial links, tip links, top connectors, shaft connectors, and ankle links (Fig. 1). The kinocilial links couple the kinocilium to the stereocilia that lie immediately adjacent, and the remaining link types are located at different points or regions along the length of each stereocilium. In all stereocilia bar those in the highest row, a single obliquely inclined tip link connects the distal tip to the shaft of a neighboring taller stereocilium. The top connectors lie just below the tip links, shaft "connectors" extend over much of the surface of each stereocilium but are concentrated around the base of the hair bundle in some types of hair cell, and the ankle links are located in or just above the tapered region at the base of each
A

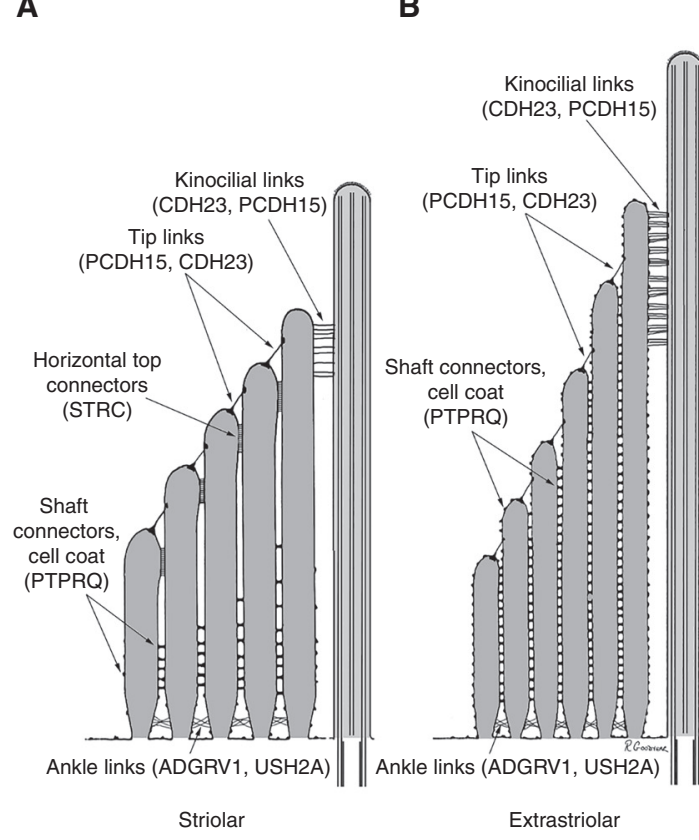

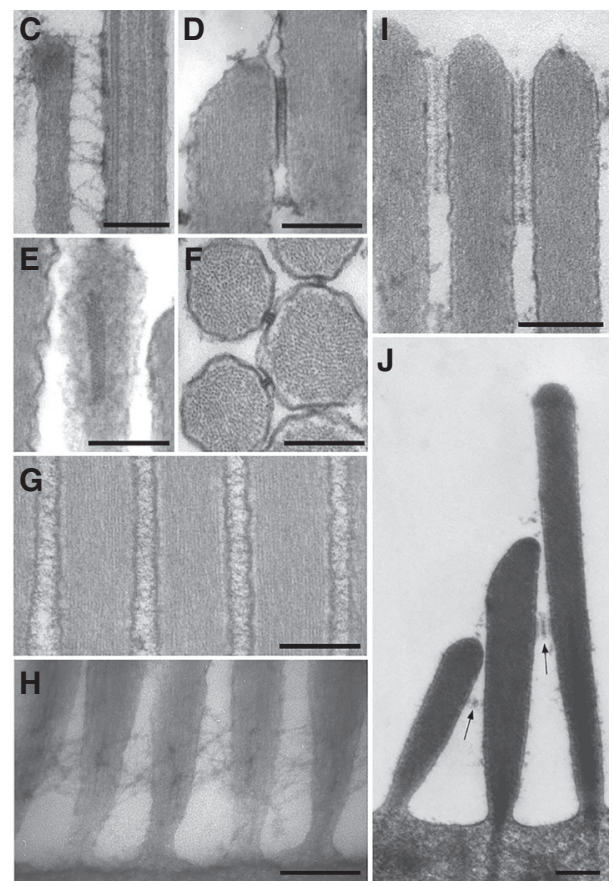

Figure 1. Structure and distribution of link types. $(A, B)$ Diagrams illustrating the distribution of the five different link types in the hair bundles of hair cells located in $(A)$ the striolar and $(B)$ the extrastriolar regions of the chicken utricle. Proteins contributing to the different links are indicated in brackets. $(C-H)$ Transmission electron micrographs illustrating the structure of $(C)$ kinocilial links, $(D)$ tip link and top connector (longitudinal section), $(E)$ top connector (transverse section), $(F)$ top connector (en face section), $(G)$ shaft connectors, and $(H)$ ankle links in the avian inner ear. Transmission electron micrographs showing location $(I)$ and details $(J)$ of the top connectors (arrows in $J$ ) seen in mouse cochlear outer hair cells (OHCs). Scale bars, $200 \mathrm{~nm}$. (Images are courtesy of Richard Goodyear.) 
stereocilium. The tip link is the only link type that is obliquely inclined and uniquely oriented along the hair bundle's axis of mechanosensitivity and it was recognized, when it was first discovered by electron microscopy in the mid1980s, as being ideally suited for gating a mechanosensitive ion channel (Pickles et al. 1984). In light of the paucity of material available in the ear for biochemical studies, it took all of 20 years and a combination of genetics and cell biology to identify cadherin 23 (CDH23) and protocadherin 15 (PCDH15) as principle components of the tip link (Goodyear and Richardson 2003; Siemens et al. 2004; Sollner et al. 2004; Ahmed et al. 2006). Determining and deciphering the functions of all the various link types has relied heavily on a genetic approach and considerable insight has been derived from the analysis of spontaneous and transgenically engineered mouse mutants. In this review, we will briefly summarize the structure of each link type and its associated proteins, most all of which are the products of genes that cause human hereditary deafness, and discuss the insight into their function that has been gained from various mouse models and other approaches.

\section{ANKLE LINKS}

Ankle links have been described in the vestibular and auditory hair bundles of a number of species (Csukas et al. 1987; Jacobs and Hudspeth 1990; Goodyear and Richardson 1992). These links are formed by long (up to $200 \mathrm{~nm}$ ) thin ( $\sim$-nm diameter) filaments and are concentrated in a region lying just above the point where the stereocilia insert into the cuticular plate, creating a web-like mesh that extends over a distance of $\sim 0.5 \mu \mathrm{m}$ up the hair bundle in mouse hair cells. In the functionally mature chick inner ear, ankle links are present in all types of hair bundles, whereas in the mouse cochlea they are only present in between postnatal day (P)2 and P12, disappearing before the onset of hearing (Goodyear et al. 2005). Current evidence indicates two large transmembrane proteins, USH2A and ADGRV1, may contribute to the ankle link filaments seen by electron microscopy. Both are the products of genes responsible for type 2 Usher syndrome, a disease that causes congenital deafness and progressive blindness.

Usherin (now known as USH2A) is one of four genes causing type 2 Usher syndrome, and the largest isoform of USH2A is predicted to be a single-pass transmembrane protein with a large ectodomain comprising single or multiple repeats of domains characteristic of extracellular matrix molecules: fibronectin type 3 repeats and four different types of laminin domain (Eudy et al. 1998; van Wijk et al. 2004). Reverse transcription polymerase chain reaction (RT-PCR) analysis of hair cells isolated from cochleae at P6 revealed the expression of USH2A transcripts encoding transmembrane domain-containing isoforms, and antibodies directed against the predicted cytoplasmic domain of USH2A provided evidence that the spatiotemporal expression pattern was similar to that previously described for ankle links in the cochlear hair cells of the mouse ear (Adato et al. 2005a). An Ush2a null mutant mouse that was created by Liu and colleagues (Liu et al. 2007) has elevated distortion-product otoacoustic emission (DPOAE) thresholds for $\mathrm{f} 2$ frequencies $>15 \mathrm{kHz}$ and a loss of basal-coil hair cells by 4 months of age. Hair bundle morphology is not, however, obviously affected in the mid-frequency region of the cochlea, and it is not known whether ankle links are present during development of the cochlea in this Ush $2 a^{-/-}$mutant mouse.

The adhesion G-coupled receptor V1 (ADGRV1), also known by many names, including the very large G-protein receptor 1 (VLGR1) and monogenic audiogenic seizure susceptible (MASS1), is a product of the USH2C locus and one of the largest cell-surface proteins known (640 kDa) (McMillan et al. 2002; Weston et al. 2004). The longest isoform of ADGRV1 has a serpentine seven-pass transmembrane domain and a large ectodomain containing multiple (35) calcium-binding Calx-B repeats, an epilepsy-associated repeat (EAR) domain and a pentraxin domain (McMillan et al. 2002; Weston et al. 2004). In the chick ear, ankle links are sensitive to brief treatment with the calcium chelator BAPTA and ankle link filaments can be labeled by monoclonal antibodies (mAbs) E40 and H28 (Goodyear and Richardson 1999; McGee et al. 
2006). These mAbs also react with the calyceal processes that surround the connecting cilium in the photoreceptors of the bird eye, and proteomic analysis of the antigen recognized by $\mathrm{mAb}$ $\mathrm{H} 28$ in the chick retina revealed it was an avian ortholog of ADGRV1 (McGee et al. 2006). Two Adgrv1 knockout models have been created (McMillan and White 2004; Yagi et al. 2007). Ankle links cannot be detected by transmission (McGee et al. 2006) or scanning (Michalski et al. 2007) electron microscopy in the early postnatal cochlear hair cells of these mouse mutants, and subtle hair bundle defects are first observed at P2, just after the time at which definitive ankle links are first observed by electron microscopy. The hair bundles located throughout the cochlea in these Adgrv1 ${ }^{-/-}$mutant mice subsequently deteriorate, becoming progressively disorganized, and eventually there is a loss of both inner (IHCs) and outer hair cells (OHCs) from the basal, high-frequency end of the cochlea, coupled with an elevation of auditory brainstem response $(\mathrm{ABR})$ thresholds across the entire frequency range tested (2-32 kHz), and a complete absence of DPOAEs at all $\mathrm{f} 2$ frequencies tested (2-20 kHz) (McGee et al. 2006).

Although mechanoelectric transduction (MET) currents of normal or diminished amplitude can be recorded from the hair cells of Adgrv1 $1^{-/-}$mice at P7, "paradoxical" MET currents can be also recorded from these cells in response to relatively large deflections of the hair bundle in the negative direction (Michalski et al. 2007). These "paradoxical" MET currents are unlikely to be the "reverse-polarity" current that is transiently expressed in embryonic hair cells and declines after birth with the emergence of normal polarity currents (Beurg et al. 2016) for two reasons. First, unlike the "reverse-polarity" currents, most of the MET currents that are recorded by hair-bundle stimulation in the inhibitory direction in Adgrv1 $1^{-/-}$hair cells exhibit fast adaptation with time constants similar to the currents recorded when hair bundles are deflected in the excitatory direction. Second, these currents were recorded when hair bundles were stimulated with a stiff glass probe that is unlikely to stimulate the apical surface of the hair cells where the PIEZO2 channels that underlie the reverse polarity current are now known to be located (Beurg and Fettiplace 2017; Wu et al. 2017). These paradoxical currents are therefore likely to be related to the MET channels themselves and reflect the decreased cohesion of the hair bundle in Adgrv1 $1^{-1-}$ mice at P7.

A number of proteins have been shown to colocalize in the ankle link region of the hair bundle and/or interact directly (or have the potential to interact indirectly) with the cytoplasmic domains of USH2A and ADGRV1, each of which has a class 1 PDZ domain-binding motif at its carboxyl terminus. These include the PDZ domain containing proteins harmonin (USH1C), whirlin (WHRN), and PDZ domain protein 7 (PDZD7), and the actin-based myosin motor myosin VIIA (MYO7A) (Boeda et al. 2002; Adato et al. 2005b; Reiners et al. 2005; van Wijk et al. 2006; Michalski et al. 2007; Grati et al. 2012; Chen et al. 2014; Zou et al. 2017). USH1C and MYO7A are the products of the genes causing Usher type IC (Bitner-Glindzicz et al. 2000; Verpy et al. 2000) and Usher type IB (Weil et al. 1995), respectively, WHRN is a product of the USH2D gene (Mburu et al. 2003; Ebermann et al. 2007), and PDZ7 is a modifier of USH2A (Ebermann et al. 2010). A third transmembrane protein, the tight-adherens junctionassociated protein vezatin (VEZT) (Küssel-Andermann et al. 2000) has also been reported to be present in the ankle link region of the hair bundle (Michalski et al. 2007). These findings, along with observations showing the mislocalization of ADGRV1 in mice with mutations in Myo7a and Whrn and, reciprocally, the mislocalization of USH2A and VEZT in Adgrv1 $1^{-/-}$mice have led to a putative model for the ankle link complex (see Fig. 2), in which the PDZ domain proteins provide a scaffold for the three transmembrane proteins and, together with MYO7A, couple the complex to the F-actin core of the stereocilium (Michalski et al. 2007).

Although this model represents a satisfactory working hypothesis, there are a number of outstanding issues. As indicated above, there is no definitive evidence from the Ush $2 a^{-1-}$ mice that have been generated and studied thus far, or from immunogold labeling studies, that the ectodomain of the long isoform of USH2A con- 


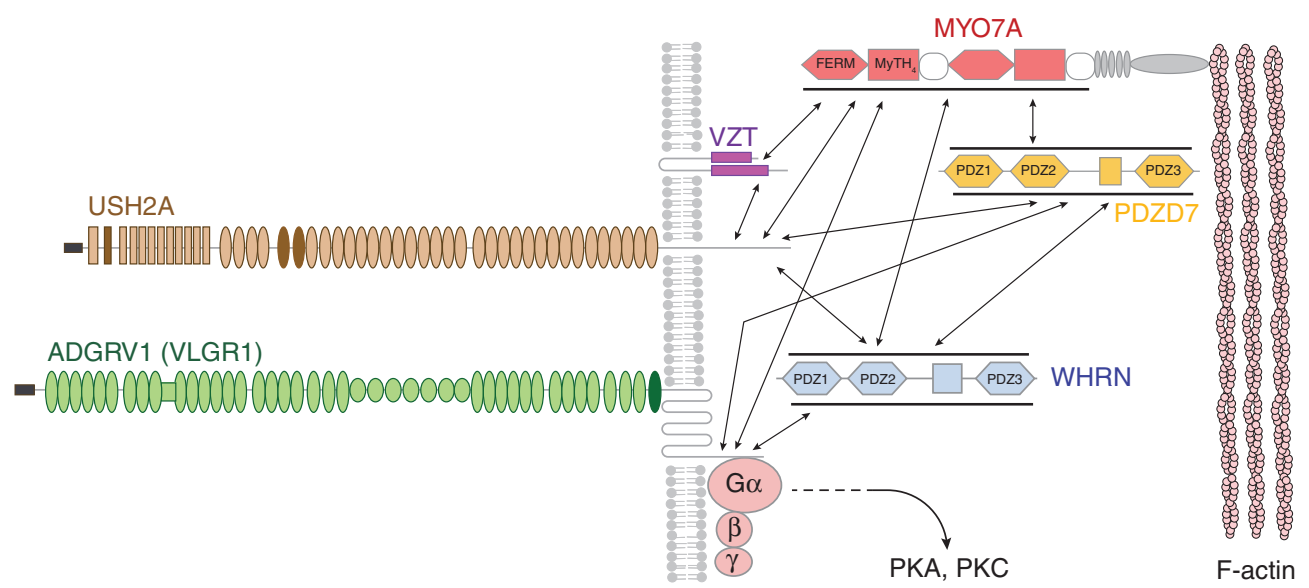

Figure 2. The ankle link complex. Diagram illustrating proteins currently thought to contribute to the ankle link complex, protein-protein interactions demonstrated via pull-down assays or surmised of basis of localization studies, and the possible signaling pathways via protein kinase $\mathrm{A}(\mathrm{PKA})$ and protein kinase $\mathrm{C}(\mathrm{PKC})$. Interactions between individual PDZ domains of whirlin and PDZ7 domains have been simplified for the sake of clarity. (From Michalski et al. 2007; adapted, with permission, from the Society for Neuroscience (c) 2007.)

tributes to the long filaments observed in the ankle link region. Furthermore, it is not known with which proteins the ectodomains of ADGRV1 and USH2A interact. Do they interact homophilically, heterophilically, or with as-yet unidentified proteins on the opposing stereocilial membrane? Or, is $\mathrm{Ca}^{2+}$ the ligand for ADGRV1? Finally, although ADGRV1 is a G-protein-coupled receptor, the details of the downstream signaling pathway remain to be resolved. Adenylate cyclase 6 (AC6) is localized to the ankle link region in cochlear hair cells and the loss of ADGRV1 causes a dramatic up-regulation of AC6 in the hair bundle (Michalski et al. 2007), possibly as a compensatory response, but does the ankle link complex only signal through protein kinase A (PKA)?

Like many adhesion class receptors, ADGRV1 has a G-protein-coupled receptor cleavage site lying just upstream of (external to) the 7TM domain and is likely to be proteolytically cleaved at this site with the two resultant fragments ( $\alpha$ for ectodomain, and $\beta$ for the combined 7TM and cytoplasmic domains) remaining covalently associated. Although the large size of ADGRV1 complicates exploration of its signaling pathways in heterologous cell systems, two recent studies have explored the use of small- er fragments. Using a construct containing five as opposed to 35 Calxb repeats, and truncated versions thereof, Ptacek and colleagues (Shin et al. 2013) provided evidence that, in response to extracellular $\mathrm{Ca}^{2+}$, ADGRV1 activates PKA

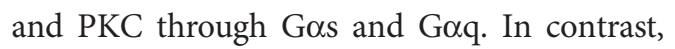
Sun and coworkers (Hu et al. 2014) have provided evidence that the $\beta$ fragment is constitutively

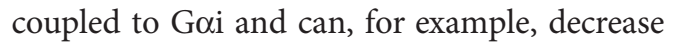
forskolin-induced cAMP production, with this inhibitory activity being negatively regulated (i.e., decreased) by the inclusion of sequence located upstream and by coexpression with PDZD7, but not by coexpression with either USH1C or WHRN. Clearly there remain many options for pathways that could be activated or inactivated downstream of ADGRV1 engaging its ligands or otherwise during hair-bundle development.

\section{SHAFT CONNECTORS}

In hair bundles that have been fixed for transmission electron microscopy in the presence of the cationic dye ruthenium red, shaft connectors are seen as electron dense particles that are suspended between adjacent stereocilia by several fine filaments. When hair cells are fixed in the 
presence of tannic acid, dense particles are not observed but numerous fine filaments are seen forming a fine mesh that spans the gap between neighboring stereocilia (Goodyear and Richardson 1992). This mesh-like material resembles an extended cell surface coat and is also found in the tapered region of the stereocilia, on the apical nonstereociliary surface of the hair cells, and on the outwardly facing surfaces of the stereocilia that lie around the edge of the hair bundle. The distribution of shaft connectors on the hair bundle varies according to type of hair cell in question (see Fig. 1A,B) and the developmental age, being restricted to the basal end of mature hair bundles in the auditory organs, the striolar regions of the maculae and the peripheral regions of the cristae. In the extrastriolar regions of the maculae and in the peripheral regions of the cristae, shaft connectors are distributed over the entire surface of the hair bundle (Goodyear and Richardson 1992).

The distribution of this cell surface feature on chick hair cells closely correlates with that of the hair-cell antigen (HCA), a 275-kDa Triton X-100 soluble antigen originally defined by a $\mathrm{mAb}$ that specifically labels the apical ends of hair cells in the avian inner ear (Richardson et al. 1990) and is one of the earliest markers for hair bundles in the developing avian inner ear (Bartolami et al. 1991). Subsequent studies identified the HCA as a receptor-like PTPRQ (Goodyear et al. 2003), a protein that is now known to be a product of the DFNB84 locus (Schraders et al. 2010) and from proteomic analysis (see Krey and Barr-Gillespie 2018 ) is, along with the plasma membrane $\mathrm{Ca}^{2+}$ ATPase PMCA2 (now ATP2B2), one of the two most abundant membrane proteins present in the hair bundle. The longest isoform of PTPRQ is predicted to be a single-pass transmembrane protein with large ectodomain comprising $18 \mathrm{fi}$ bronectin type 3 repeats and a shorter cytoplasmic domain that can catalyze the removal of phosphate groups from the $3^{\prime}$ and $5^{\prime}$ positions of the inositol ring and therefore dephosphorylate a variety of phospholipids including PIP2 and PIP3 (Oganesian et al. 2003). Although originally described (on the basis of primary sequence data) as a protein tyrosine phosphatase, PTPRQ has low phosphotyrosine activity. Two additional splice variants of PTPRQ have been described, one of which lacks the catalytic domain and the other of which is predicted to be a soluble cytoplasmic protein with inositol phosphatase activity (Seifert et al. 2003).

Consistent with PTPRQ acting as an inositol lipid phosphatase, the distributions of PIP2 and PTPRQ are mutually exclusive in hair cells of the bullfrog saccule; PTPRQ is found on the apical surface of the hair cell and around the lower end of the hair bundle, whereas PIP2 is excluded from the region where PTPRQ is present and is localized toward the tip of the bundle (see Fig. 3; Hirono et al. 2004). Studies of transgenic mice in which either the transmembrane or the cytoplasmic catalytic domain (CAT) of PTPRQ have been deleted, both of which are likely to be functionally null mutants, indicate that PTPRQ is required for the normal maturation but not the early development of hair bundles in both the auditory and the vestibular system (Goodyear et al. 2003). The exact details of the hair-bundle phenotype seen in these mutants vary according to hair-cell type, but a loss of shaft connectors and fusion of stereocilia was seen in all types of hair cell except in the OHCs of the cochlea. In the latter, a shortening and eventual loss of stereocilia was observed, whereas in the striolar regions of the maculae the fused hair bundles were elongated (Goodyear et al. 2003, 2012).

It has been suggested that the basally restricted expression pattern of PTPRQ observed in the hair bundles of some types of hair cells may be generated by an interaction with the minus-end-directed F-actin motor, myosin VI (MYO6), with active MYO6-directed transport of PTPRQ toward the base of each stereocilium counteracting passive diffusion (Sakaguchi et al. 2008). Consistent with this hypothesis, MYO6 is concentrated around the base of stereocilia and its loss in the Snell's waltzer mouse leads to a fusion of the stereocilia similar to that seen in the IHCs of the cochlea and the vestibular hair cells of Ptprq-CAT knockout mice (Self et al. 1999; Goodyear et al. 2003, 2012; Sakaguchi et al. 2008). Furthermore, in the Snell's waltzer mice, PTPRQ is no longer restricted basally and localizes over the entire surface the fused hair bundles of IHCs (Sakaguchi et al. 2008). 

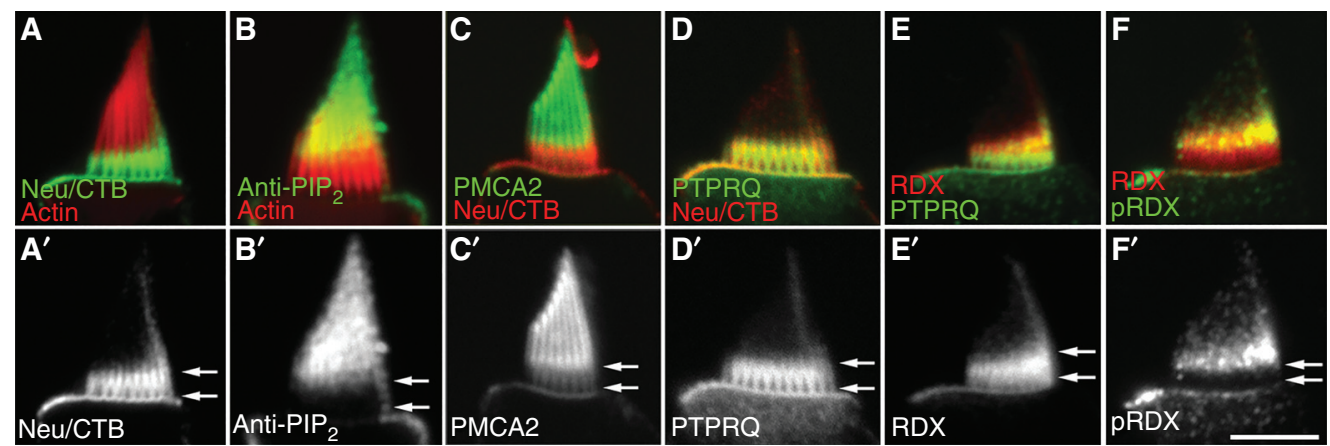

Figure 3. Distribution of the receptor-like inositol lipid phosphatase PTPRQ, membrane lipids, and radixin in a hair bundle. (Top row) Confocal images showing hair bundles of isolated frog saccular hair cells double labeled for $(A)$ gangliosides and F-actin, $(B)$ PIP2 and F-actin, $(C)$ the plasma membrane ATPase PMCA2 and gangliosides, (D) PTPRQ and gangliosides, $(E)$ radixin (RDX) and PTPRQ, and (F) radixin and phospho (T564) radixin (pRDX). (Bottom row) Corresponding single channel images from upper row showing distributions of $\left(A^{\prime}\right)$ gangliosides, $\left(B^{\prime}\right)$ PIP2, $\left(C^{\prime}\right)$ PMCA2, $\left(D^{\prime}\right)$ PTPRQ, $\left(E^{\prime}\right)$ RDX, and $\left(F^{\prime}\right) \mathrm{pRDX}$ in isolation. Gangliosides are monosialylated gangliosides that were revealed with 488-chlolera toxin B labeling following treatment of fixed samples with neuroaminidase. Scale bar, $5 \mu \mathrm{m}$. (From Zhao et al. 2012; adapted, with permission, from the Society for Neuroscience (C) 2012.)

The basal restriction of hair-bundle PTPRQ in frog saccular hair cells also correlates with the distribution of GM1 gangliosides (as revealed by cholera toxin B staining following treatment with neuraminidase) in the apical membrane, and with the presence of radixin (RDX), a protein that couples membranes to the actin-based cytoskeleton (Fig. 3). Additionally, the activated form of RDX that is phosphorylated at T564 following binding to PIP2 is further restricted to a narrow region at the interface between the PIP2-rich distal region of the hair bundle and the PIP2-free basal region where PTPRQ is located (Zhao et al. 2012). As in mice lacking PTPRQ or MYO6, a fusion of stereocilia is also seen in the hair bundle of $R d x^{-1-}$ mice (Kitajiri et al. 2004). Together, these observations suggest the localized distribution of PTPRQ plays a key role in regulating PIP2 distribution at the apex of the hair cell and, as a consequence, the activity of cytoskeletal-associated proteins. These include RDX and possibly also CLIC5, the loss of which in the jitterbug ( $j b g / j b g)$ mutant mouse also causes the fusion of hair bundles (Salles et al. 2014).

Finally, it should be noted that PTPRQ, although nominally a receptor-like inositol lipid phosphatase, is, like ADGRV1, an orphan recep- tor and it is not known how its activity is regulated. Can the extracellular domains interact homophilically with one another in cis or in trans, or is there an as yet unidentified ligand? There are 33 potential sites for $\mathrm{N}$-glycosylation in the ectodomain of PTPRQ and there is evidence that there may be at least three glycoforms expressed in different types of hair cell and/or at different points in developmental time (Nayak et al. 2011). Some or all of these glycoforms are likely to be substituted with chondroitin sulfate GAG chains, which could account for the chondroitinase-sensitive electron-dense particles that are seen associated with the shaft connectors in ruthenium red stained hair bundles and may also, via adhesive or repellent electrostatic interactions, modulate the spacing between adjacent stereocilia (Nayak et al. 2011). The potential for complexity is high and much remains to be learned about how one of the major glycoproteins of the hair cell's apical membrane regulates the final maturation and maintenance of the hair bundle.

\section{TOP CONNECTORS}

Top connectors (also known as side links, sideto-side links, horizontal top or tip connectors, or 
lateral links to distinguish them from the obliquely inclined tip links) vary in structure, according to species and the type of hair cell. In mammals, the top connectors of the cochlear $\mathrm{OHCs}$ have a characteristic zipper-like structure; fine filaments project from the membranes of opposing stereocilia and condense within a central extracellular density (see Fig. 1J; Tsuprun and Santi 1998, 2002; Goodyear et al. 2005). Although the top connectors of cochlear IHCs bridge the sides of stereocilia both across and between different rows as in OHCs, a central density has not been observed and may be absent in this type of hair cell (Prieto and Merchan 1986; Tsuprun et al. 2003). In fish, frogs, and birds, the top connectors are structurally distinct from those in the cochlea and are composed of tightly packed arrays of short, stubby elements $(\sim 20 \mathrm{~nm}$ long and $6 \mathrm{~nm}$ in diameter in chick) that span the gap between the closely opposed plasma membranes of adjacent stereocilia (see Fig. 1A,D-F; Neugebauer and Thurm 1985, 1986; Jacobs and Hudspeth 1990; Nagel et al. 1991; Goodyear and Richardson 1992). In those sensory organs of the chick inner ear that have been examined in detail (basilar papilla and utricle), these arrays of connectors are $25-50 \mathrm{~nm}$ in width and can extend for at least $400 \mathrm{~nm}$ along the long axis of the sterocilium (Goodyear and Richardson 1992), whereas in the ampullary organ of the frog they can extend along this axis for up to $3 \mu \mathrm{m}$ (Nagel et al. 1991). As in mammals, these top connectors couple adjacent stereocilia both within and across the rows, much like the ankle links. In the chick utricle, the horizontal top connectors appear restricted to those hair bundles in which the shaft connectors are absent from the apical end of the hair bundle, suggesting functional redundancy (Goodyear and Richardson 1992).

In mice, stereocilin (STRC), a product of the DFNB16 locus originally identified using a candidate deafness gene approach (Verpy et al. 2001), is now known to be associated with the top connectors of OHCs, as well as with the attachment crowns that couple the extreme tips of the tallest stereocilia in the OHCs to the overlying tectorial membrane (Verpy et al. 2008, 2011). As STRC is not detected in the hair bundles of IHCs, it may contribute to the prominent central density that has thus far only been described in the top connectors of OHCs (see above). STRC is predicted to be a protein with a mass of $\sim 180$ $\mathrm{kDa}$ and has distant homology to mesothelin, a protein expressed by mesothelial cells that may be involved in cell adhesion, and otoancorin (OTOA), a product of the gene causing DFNB22 (Zwaenepoel et al. 2002) now known to be required for attachment of the tectorial membrane to the spiral limbus (Jovine et al. 2002; Sathyanarayana et al. 2009; Lukashkin et al. 2012). Nptn55, a splice variant of neuroplastin (NPTN) that is expressed in the distal end of the hair bundle of developing OHCs, may also be component of the tectorial membrane attachment links (Zeng et al. 2016), but STRC and Npt55 do not appear to interact with one another and their potential ligands in the tectorial membrane remain unknown.

STRC is expressed in the kinocilia of developing OHCs at P2, and it appears in all three rows of stereocilia between P10 and P12, coincident with the time at which clearly defined top connectors are first observed by transmission electron microscopy (Goodyear et al. 2005; Verpy et al. 2011). In Strc ${ }^{-1-}$ mice, top connectors fail to form, and a distinct phenotype becomes visible in the hair bundles of the OHCs at P10, with the distal tips of the stereocilia in all three rows being no longer aligned precisely and exhibiting a degree of disorganization (Verpy et al. 2011). Although these Strc ${ }^{-/-}$mice eventually become deaf, auditory thresholds, as determined by measurements of the compound action potential (CAP), are nearly normal at P14, at the onset of hearing (Verpy et al. 2008). Intriguingly, despite near normal sensitivity and evidence that the tectorial membrane is functionally attached/coupled to the hair bundles of the OHCs, distortion product otoacoustic emissions cannot be detected in these mice and suppressive two-tone masking is reduced. Horizontal top connectors may therefore be required for the cohesion of the stereocilia and thereby ensure a cooperative gating of the MET channels required for productive two-tone interactions (Verpy et al. 2008; Avan et al. 2013).

Although STRC is clearly required for top connector formation in cochlear OHCs, it is not 
Hair-Bundle Links

found in the hair bundles of mature IHCs. Furthermore, although human STRC is predicted by some algorithms to be produced as a GPIanchored glycoprotein, mouse STRC is not, leaving it unclear as to how it is attached to the membrane of the stereocilium. The proteins that form the horizontal top connectors of IHCs and those that may be additionally associated with top connectors of OHCs along with STRC therefore remain to be identified, as do those that form the structurally distinct top connectors that are seen in frogs, fish, and birds. The latter resemble, at least in transmission electron micrographs, the septate junctions found in the epithelial cells of invertebrates (see Furuse and Izumi 2017 for review of these junctions). Whether this similarity is reflected in protein composition remains to be determined.

\section{TIP LINKS}

Tip links have, in light of their proposed pivotal role in MET, attracted considerable attention and are probably the best characterized connectors of the hair bundle. A freeze-fracture deepetch analysis of chemically fixed hair bundles from the inner ears of the guinea pig and the frog provided evidence that the tip link is comprised of a pair of closely intertwined, helically coiled protofilaments with a pitch of $60 \mathrm{~nm}$, which form a single filament with a diameter of 8-10 nm (Fig. 4; Kachar et al. 2000). At their upper end and within $10-50 \mathrm{~nm}$ of the adjacent taller stereocilium, many of these tip-link filaments were seen to bifurcate, and at the lower end two or three branches were seen to connect the tip link to the shorter stereocilium. In thin sections of hair bundles, distinct submembranous densities, which are now known as the upper and lower tip link densities, are observed at the sites at which the top and the bottom of the tip link attach to the membranes of the stereocilia (Furness and Hackney 1985; Jacobs and Hudspeth 1990). Whereas a survey of published transmission electron micrographs suggests tip length can be quite variable, both within and between species, this may be due to variable shrinkage during fixation. A length range of 150-185 nm was found in one study of the mammalian (guinea pig) cochlea (Furness et al. 2008).

Tip links are known to be sensitive to calcium chelation (Assad et al. 1991) and a number of studies that were published at the turn of the 21 st century identified mutations in genes en-
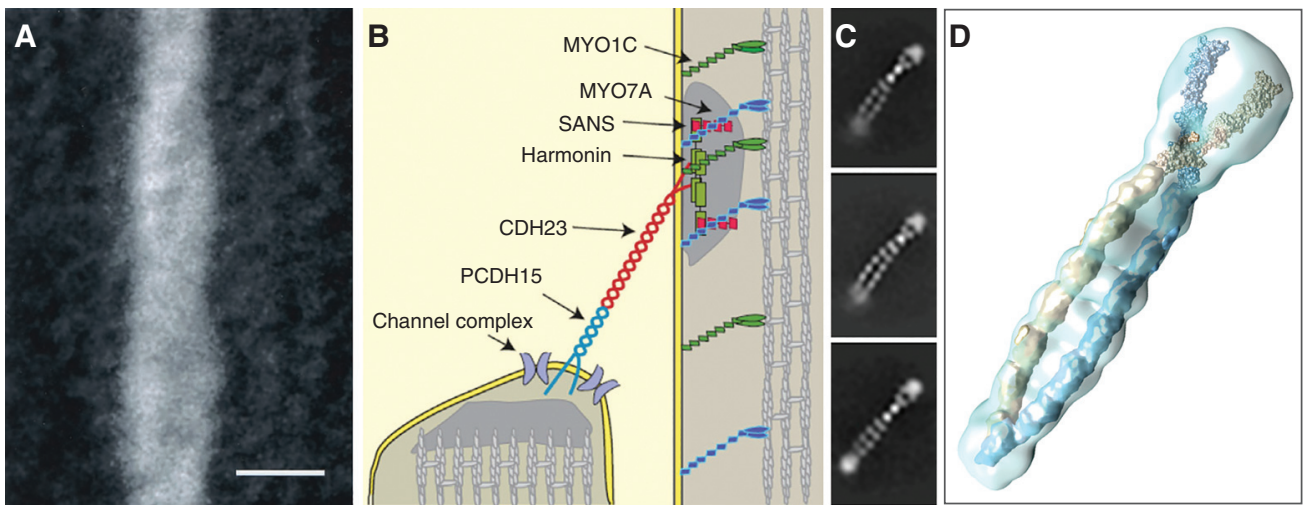

Figure 4. Tip-link structure. (A) Freeze etch image showing a segment of a tip link from a chemically fixed, fast frozen frog saccular hair cell. The link appears to be formed from two helically wound filaments with a pitch of $\sim 60 \mathrm{~nm}$. Scale bar, $10 \mathrm{~nm}$. (From Kachar et al. 2000; adapted, with permission, from the National Academy of Sciences ( $)$ 2018.) (B) Diagram illustrating the components of the tip link and it associated proteins. (C) 2D class averages of negatively stained images of PCDH15 EC1-11 molecules that were expressed in mammalian cells and purified by size exclusion chromatography. The PCDH dimer forms a parallel double helix. (D) 3D class average of the PCDH15 dimer with crystal structure for EC1-3 and simulated $11 \AA$ electron density for EC4-10 superimposed. (Panels $B-D$ from Dionne et al. 2018; adapted, with permission from Elsevier (C) 2018.) 
coding $\mathrm{CDH} 23$ and PCDH15 as the cause of type 1 Usher syndrome (Ahmed et al. 2001; Alagramam et al. 2001; Bolz et al. 2001; Bork et al. 2001). CDH23 (underlying USH1D) and PCDH15 (underlying USH1F) are single pass transmembrane proteins with, respectively, 27 and 11 extracellular cadherin (EC) repeats in their ectodomains. A loss of tip links in the zebrafish sputnik mutant, which is mutated in $c d h 23$, immunolabeling of the tip links in mice and fish with antibodies to $\mathrm{CDH} 23$, and identification of the tip-link antigen, an antigen defined by a monoclonal antibody that specifically labels the tip and kinocilial links of hair bundle in the avian inner ear as PCDH15 provided the evidence that both cadherins may contribute to the tip link (Siemens et al. 2004; Sollner et al. 2004; Ahmed et al. 2006). Subsequently, it was shown that the ectodomains of the two proteins can both form parallel homodimers when expressed in vitro, that these homodimers can interact via their amino termini, and that (using high resolution immunogold labeling) $\mathrm{CDH} 23$ localizes to the upper end of the tip link and PCDH15 to the lower end (Kazmierczak et al. 2007). With each cadherin repeat estimated to be $4.5 \mathrm{~nm}$ in length, the two proteins could, in principle, form a tip link that is $\sim 170 \mathrm{~nm}$ long.

Cocrystallization of the complex formed by the interacting amino-terminal domains, EC12, of $\mathrm{CDH} 23$ and PCDH15 has revealed these domains form an extended antiparallel heterodimeric handshake that is predicted, from steered molecular dynamic simulations, to withstand the forces imposed on the tip link during transduction (Sotomayor et al. 2010, 2012). Although this study and the deep-etch freeze fracture study of Kachar et al. (2000) both suggested the tip link was unlikely to be the elastic element proposed to gate the hair-cell MET channel, a more recent study (Araya-Secchi et al. 2016) has provided evidence that a bent, noncanonical, calcium-free linker between EC9 and EC10 of PCDH15 may confer a limited degree of tertiary state elasticity (an extension of $\sim 4 \mathrm{~nm}$ ). Furthermore, there are a number of other linker regions between adjacent EC domains in $\mathrm{CDH} 23$ that lack one or more of the three $\mathrm{Ca}^{2+}$ binding sites that stabilize EC-EC domain interactions and may therefore modify the elasticity of the link (see Jaiganesh et al. 2018 for further details). Finally, a very recent study (Dionne et al. 2018) combining single-particle and crystallographic analyses has shown that the ectodomain of PCDH15 forms cis-homodimers when expressed in vitro that interact via adhesive interfaces contained, at one end, within EC2 and EC3 and, at the other, between the membrane proximal region (with this region now being referred to as a "PICA" domain, for PCDH15 interacting-channel-associated domain). Mutations in residues within the EC2-EC3 interface that interfere with cis-homodimerization also impair a rescue of mechanotransduction when introduced into full-length PCDH15 constructs injectoporated into transduction-deficient $P c d h 15^{\text {av33/av3J }}$ hair cells in vitro, and an unwinding of the helical structure for the homodimer predicts an extension of $\sim 3.5 \mathrm{~nm}$, almost as much as that predicted by a straightening of the EC9-EC10 bend in PCDH15 by Sotomayor and colleagues (Araya-Secchi et al. 2016). Although the data from these studies discussed above are within the working extensions of the gating spring $(10-20 \mathrm{~nm})$ and provide evidence that the tip link is elastic, they do not account for the distance of $100 \mathrm{~nm}$ or more over which the gating spring is thought to extend in response to large stimuli (Sotomayor et al. 2005).

As described above with the transmembrane components of the ankle links, $\mathrm{CDH} 23$ and PCDH15 are known to interact via their intracellular carboxy-terminal domains with a number of other proteins, many of which are also encoded by genes that are associated with Usher's syndrome. These proteins form part of a complex network that allows the cytoplasmic domain of $\mathrm{CDH} 23$ to interact with the F-actin cytoskeleton of the stereocilium and membrane phospholipids (Boeda et al. 2002; Siemens et al. 2002; Pan et al. 2009; Bahloul et al. 2010) (for previous reviews, see El-Amraoui and Petit 2005; Kremer et al. 2006; Reiners et al. 2006; Pan and Zhang 2012; Cosgrove and Zallocchi 2014). The cytoplasmic domain of CDH23 interacts with the PDZ-domain protein harmonin (USH1C), a scaffolding protein composed of 
four ankyrin repeats called sans (USH1G), and MYO7A (USH1B). The harmonin b isoform involved in this complex binds to F-actin (Boeda et al. 2002; Lefevre et al. 2008; Grillet et al. 2009; Michalski et al. 2009), and switches between an open and a closed conformation that is likely to be regulated by USH1G binding and, in turn, regulates interactions with $\mathrm{CDH} 23$ (Bahloul et al. 2017). Harmonin b has also been shown to limit the full relaxation of the tip link (Michalski et al. 2009). At the lower end of the tip link, the cytoplasm domain of PCDH15 has the potential to interact with at least three proteins, including a two-pass transmembrane protein of the inner ear (TMIE), a four-pass transmembrane protein now known as lipoma HMIG fusion partner-like protein (LHFPL5), and the transmembrane channel-like proteins (TMC1/ 2) (see Corey et al. 2018; Cunningham and Müller 2018). The interactions of this multiprotein tip-link complex with the cytoskeleton may in turn be modulated by a number of other proteins including, at the top end, a myosin motor controlling tip link tension and MET channel adaptation (MYOIC) (Holt et al. 2002; Stauffer et al. 2005) and, at the bottom end, MYO15A, WHRN, two actin-associated proteins (ESPN-1 and ESPNL), and the calcium and integrinbinding protein CIB2 (Belyantseva et al. 2003; Delprat et al. 2005; Salles et al. 2009; Ebrahim et al. 2016; Giese et al. 2017).

Further complexity is generated by the presence of multiple isoforms of most all of the Usher proteins, with $\mathrm{CDH} 23$ and $\mathrm{PCD} 15$ providing no exception to the rule. There are six isoforms of CDH23 (Di Palma et al. 2001; Lagziel et al. 2005; Michel et al. 2005) and at least 24 splice variants of PCDH15 expressed in the inner ear (Ahmed et al. 2006). The transmembrane variants of PCDH15 fall into three major isoform classes, CD1, CD2, and CD3, each of which has a distinct cytoplasmic domain. Labeling studies with antibodies specific for these three classes showed that each has a different spatiotemporal expression pattern during inner ear development and indicated that the CD3 class was localized toward the tips of the stereocilia, suggesting this may be the isoform associated with the tip link (Ahmed et al. 2006). A subsequent study, however, in which three transgenic mouse lines were generated, each of which lacked one of the three major isoforms, provided evidence that the three isoforms were, at least for normal mechanotransduction, functionally redundant (Webb et al. 2011). Although the mice lacking the CD2 isoform had severely misoriented cochlear hair bundles and were profoundly deaf by 1 month of age, tip links were present and transduction currents of normal amplitude could be recorded from the cochlear hair cells of these mice at P7. While these data suggest that any one of the three transmembrane PCDH15 isoform classes may be sufficient for normal MET, a more recent study in which the CD2 isoform class was conditionally deleted after normal hair-bundle development is nearly complete and has revealed PCDH15-CD2 is an essential component of this structure in mature hair cells (Pepermans et al. 2014). Hair-bundle orientation was normal in mice homozygous for the conditional deletion at P30 and P45, but tip links were absent and the mice were profoundly deaf by P45. Furthermore, PCDH15-CD2 was found to localize to the tip link.

\section{KINOCILIAL LINKS}

Some of the earliest electron microscopic studies of the hair bundle in the saccule of the bullfrog described the presence of a meshwork of fine fibrous links coupling the kinociliary bulb, a swelling found at the tip of the kinocilium in this species, and the immediately adjacent stereocilia (Hillman 1969). Although these kinocilial links were suggested to play a key role in mechanotransduction, a subsequent study in which the kinocilium was either removed by microsurgery or detached and stuck down onto the apical surfaces of adjacent supporting cells showed it was, in fact, dispensable for normal MET (Hudspeth and Jacobs 1979). In the vestibular system of the chick inner ear, in which the kinocilium of the hair cell does not end in a bulbous swelling, the kinocilial links are located along a distance of up to several microns along the length of the shaft of the kinocilium (Goodyear and Richardson 2003). A comparison of the ultrastructure of tip and kinocilial links in chick 
hair cells using Fourier analysis provided evidence for structural similarity, and dual immunogold labeling showed $\mathrm{CDH} 23$ and PCDH15 were both associated with the kinocilial links, with PCDH15 likely located in the kinocilium and $\mathrm{CDH} 23$ in the stereocilia (Tsuprun et al. 2004; Goodyear et al. 2010). Furthermore, like tip links, kinocilial links are both BAPTA sensitive and resistant to degradation with subtilisin, a protease that is frequently used to remove the overlying otoconial membrane prior to recording MET currents. Thus, tip and kinocilial links may well be similar structures, but their polarity with respect to the hair bundle's axis of mechanosensitivity is the opposite and the kinocilial links may, in some hair cells, be shorter than the tip links (Goodyear et al. 2010).

Although the microsurgical manipulations described above indicate the kinocilium is not required for normal mechanotransduction in frog saccular hair cells, the mechanosensitive TRP channel TRPN1 localizes to the kinocilial bulb in this species (Shin et al. 2005), and there is evidence that the kinocilium and kinocilial links may mediate mechanosensitivity (as detected by a genetically encoded calcium sensor) in the immature hair cells of developing zebrafish lateral line neuromasts (Kindt et al. 2012). Whereas the mechanosensitivity of these immature lateral line hair cells is dependent on the presence of a kinocilium, it is of reverse polarity (i.e., activated by displacement of the kinocilium toward the stereocilia) and could possibly result from gating of the anomalous, reverse-polarity currents discussed above (see section on Ankle Links) that are mediated by PIEZO2 channels located in the apical membrane close to the base of the kinocilium (Beurg and Fettiplace 2017; Wu et al. 2017). Alternatively, the mechanosensitivity mediated by the kinocilial links in the immature lateral line hair cells might be related to currents observed in shaker-2 (Myo15 $\left.5^{\text {sh2/sh2 }}\right)$ mice with similar (i.e., nonobliquely directed) links between the tip of the drastically shortened stereocilia (Stepanyan and Frolenkov 2009).

Although it is debatable whether kinocilial links can directly mediate mechanotransduction in hair cells, there is good evidence that attachment of the kinocilium to the stereocilia is re- quired for normal development of the hair bundle. PCDH15-CD2 is expressed throughout hair bundles in the developing cochlea (Ahmed et al. 2006) and at high levels at the kinocilium-stereocilia interface in vestibular hair cells (Webb et al. 2011). As discussed above, although transduction currents are normal in the PCDH15$\triangle \mathrm{CD} 2$ mice, the hair bundles are misoriented. The kinocilium is also mislocalized and no longer associated with the stereocilia, and the variably disorganized V-shaped bundles of stereocilia are not aligned with their axis of bilateral symmetry across the medial-lateral (neural-abneural) axis of the cochlear duct (Webb et al. 2011), a phenotype that resembles that seen in mice with mutations affecting either the core PCP genes or the development of the kinocilium (Montcouquiol et al. 2003, 2006; Ross et al. 2005; Jones et al. 2008). The normal asymmetric distribution of Frizzled and van Gogh-like in the cochlear epithelium is, however, unaffected in the PCDH15- $\triangle \mathrm{CD} 2$ mice and it has therefore been suggested that PCDH-CD2 lies downstream of the core PCP pathway and that its loss causes an effect similar to that of ciliary mutants (Webb et al. 2011). As the position of the kinocilium and the orientation of the stereociliary bundle in the PCDH- $\Delta \mathrm{CD} 2$ mutant mice are frequently different (i.e., they "point" in different directions), the kinocilial links appear essential for ensuring the position of the two elements of the hair bundle is coordinated. Most likely there must be continual interplay (feedback and feedforward) between the two structures and the mechanisms pulling the kinocilium to one pole of the cell and those that ensure exactly where and how the stereociliary bundle forms (see Montcouquiol and Kelley 2018).

\section{TRANSIENT LATERAL LINKS}

During the very early stages of hair-bundle development an extensive network of filaments is found between the microvilli that are the precursors of the stereocilia, the stereocilia that emerging from a subset of these microvilli, and the kinocilium (Goodyear et al. 2005). Many of these filaments, which are collectively referred to as transient lateral links, disappear as development 
proceeds or may become integrated into the more clearly defined link types that have been categorized in mature or maturing bundles. In avian auditory hair cells, ADGRV1 and PTPRQ are initially present throughout the hair bundle and come basally restricted as a function of time (Bartolami et al. 1991; Goodyear and Richardson 1999). As new membrane is most likely added at the basal end of the stereocilium these proteins must be restricted from diffusing distally as the stereocilia grow in length, presumably via their interactions with the actin-based cytoskeleton mediated by either the minus-end-directed myosin MYO6 and/or the scaffolding proteins with which they are associated. By contrast, $\mathrm{CDH} 23$ and PCDH15-CD2 become localized toward the tips of the stereocilia after the emergence of the hair bundle, and there is good evidence that this involves at least three other components of the Usher 1 complex-USH1C, sans (USH1G), and MYO7A (Boeda et al. 2002). Mice with spontaneous or engineered mutations in genes encoding the 5 Usher type 1 proteins (MYO7A, USH1C, CDH23, PCDH15, and USH1G) all have similar phenotypes (Lefevre et al. 2008), with fragmented and misoriented hair bundles being evident 1-2 days after the time at which these proteins would normally appear in the hair bundle (E16.5 for mouse OHCs). Although the hair bundles are fragmented, lateral links, albeit reduced in density, are evident within the fragmented clumps of height-ranked stereocilia in all these mice suggesting PCDH15 and CDH23 may each be able interact homophilically in trans to form a subset of the transient lateral links that are observed on developing hair bundles. In this respect, it is interesting to note that there is evidence that the short tip links that rapidly reform following BAPTA-induced loss in young postal mouse IHCs only contain PCDH15 and not CDH23 (Indzhykulian et al. 2013). Although $\mathrm{CDH} 23$ can self-associate when expressed in cells in vitro (Siemens et al., 2004), whether it can interact in a similar manner to form transient lateral links in developing hair bundles in the absence of PCDH15 remains to be determined.

Whereas the results discussed above and in preceding sections indicate the transient lateral/ kinociliary link proteins $\mathrm{CDH} 23$ and PCDH15 affect the early stages of hair-bundle development, and that the ankle link and shaft connector proteins (ADGRV1 and PTPRQ, respectively) are only required for the maintenance of hairbundle form at slightly later stages of development despite their premature appearance, the situation is clearly more complex. The use of a conditional mutant in which USH1G, a component of the upper tip link density, was deleted after the early stages of hair bundle development (after P0) shows that tip links are required for maintaining the height of the second and third rows of stereocilia in the hair bundles of mammalian cochlear hair cells (Caberlotto et al. 2011). A loss of tip links and a considerable reduction in the mean maximal MET current was observed in hair cells by P8, and the subsequent shortening of the stereocilia observed in these conditional mutants at later stages (see Fig. $5 \mathrm{~A}-\mathrm{C}$ ) provided the first experimental evidence for a theory proposed in 1988 (Tilney et al. 1988) suggesting that $\mathrm{Ca}^{2+}$ influx through the MET channel regulates actin polymerization at the tip of the stereocilium, a concept that has been further supported by in vitro data showing MET channel block in vitro causes a similar reduction in the length of second and third row stereocilia that is, furthermore, reversible (Fig. 5D,E; VélezOrtega et al. 2017).

\section{CONCLUSIONS}

Much has been learned about the structure and function of hair-bundle links over the last 30 years. Common emerging themes are the use of transmembrane proteins with large ectodomains containing multiple repeats and the coupling of the cytoplasmic domains of these link proteins through to the cytoskeletal core of the stereocilium via a small number of scaffolding proteins and a myosin motor. There is, however, much we still need to know about the how these molecular specializations of the apical compartment of the sensory hair cell contribute to its development and the way it processes stimuli. Clearly much effort has been directed at understanding the molecular structure of the tip links, but it may now be beneficial to focus on structures that do not directly gate the hair cell's MET 
G.P. Richardson and C. Petit

A

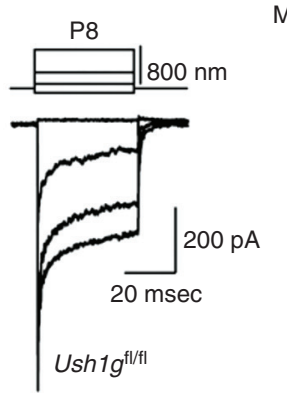

B

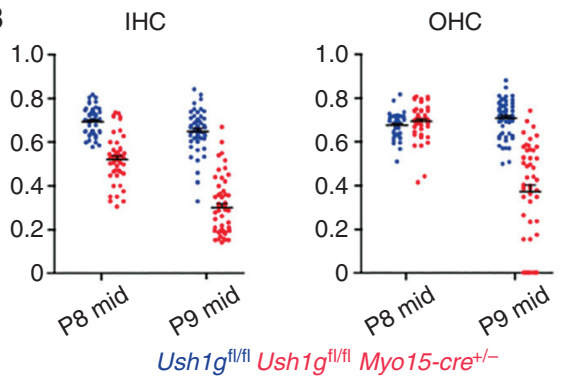

C
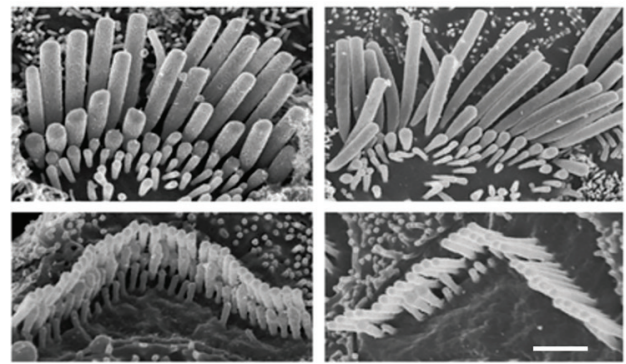

Ush1 $g^{\mathrm{fl} / \mathrm{fl}}$ Myo15-cre $\mathrm{e}^{+/-}$
D
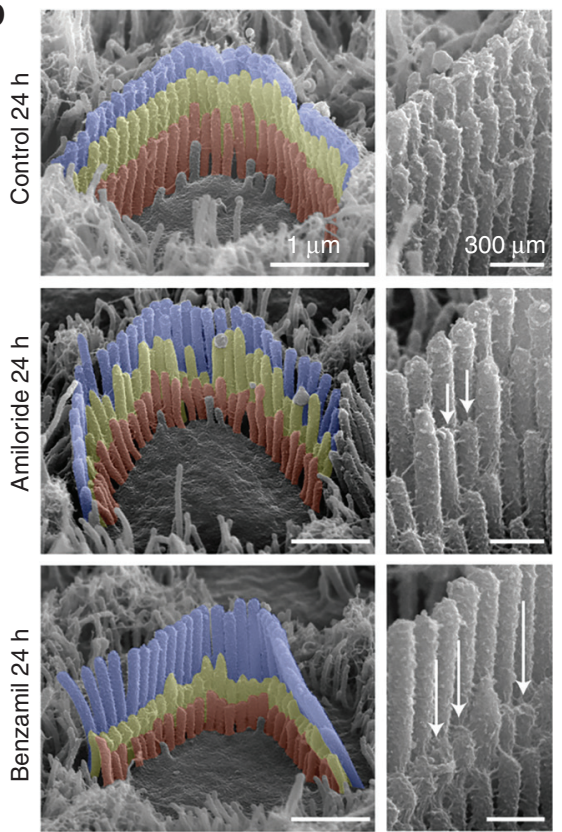

$\mathbf{E}$

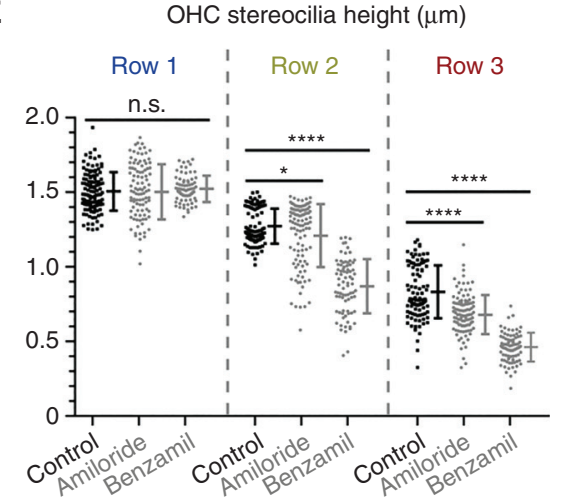

Figure 5. Tip links and transduction regulate stereocilia length. (A) Mechanoelectrical transduction (MET) currents recorded from outer hair cells (OHCs) located in the middle of the cochlea in Ush $1 g^{f l / f l}$ mice (black traces, left) and Ush1g ${ }^{f l f l}$ Myo15-cre ${ }^{+/-}$mice (right, pink) mice at P8. (B) Height of stereocilia in row 2 (R2) relative to that in row 1 (R1) in inner hair cells (IHCs) (left) and OHCs (right) in the middle of the cochlea in $U$ sh $1 g^{f l / f l}$ mice (blue) and Ush $1 g^{f l / f l} M y o 15-c^{+/-}$mice (red) mice at P8 and P9. The second row stereocilia are shorter in the IHCs of Ush1 $g^{f l / f l}$ Myo15-cre $e^{+/-}$mice at P8 and continue to shorten by P9. The second row stereocilia of the OHCs of Ush $1 g^{f l / f l}$ Myo15-cre ${ }^{+/-}$mice start to shorten at P9. (C) Scanning electron micrographs showing the hair bundles of IHCs (top) and OHCs (bottom) in the middle of the cochlea at P9 (left) and at P22 (right). Note the shortening and loss of the second and third row stereocilia. Scale bar, $1 \mu \mathrm{m}$. $(A-C$ from Caberlotto et al. 2011; adapted, with permission, from the authors in conjunction with National Academy of Sciences (C) 2011 Open Access policy.) (D) Scanning electron micrographs showing hair bundle from early postnatal mice (P4-P6) that were cultured in control medium (top), $100 \mu \mathrm{M}$ amiloride (middle), and $30 \mu \mathrm{M}$ benzamil (bottom) for 24 hours. Stereocilia have been pseudocolored; row 1 (blue), row 2 (yellow), row 3 (red). MET channel block by amiloride and benzamil cause a rapid shortening of the second and third rows. $(E)$ Quantification of data shown in $D$ above. Significant shortening is observed in rows 2 and 3 but not in row 1. n.s., Not significant. ${ }^{*} p<0.05,{ }^{* * * *} p<0.001$. ( $D$ and $E$ from Vélez-Ortega et al. 2017; adapted under the terms of the Creative Commons Attribution License.) 
channel but impact the dynamics of the hairbundle's global response. For example, little is known about the structure of the top connectors in hair cells other than OHCs, nor do we fully understand how the tectorial membrane is attached to the hair bundles of the OHCs. Considering that mutations in STRC are now recognized as a very frequent cause of human hereditary deafness (Vona et al. 2015; see also Sheffield and Smith 2018), these issues are among the many that need to be resolved if we are to reverse and repair some of the multiple causes of deafness.

\section{ACKNOWLEDGMENTS}

The authors thank Richard Goodyear and Nicholas Michalski for their help with preparing the figures. Many thanks are also due to Peter Barr-Gillespie, Gregory Frolenkov, Richard Goodyear, Nicholas Michalski, and Corné Kros for their constructive criticisms of, and advice on, earlier versions of this manuscript.

\section{REFERENCES}

${ }^{*}$ Reference is also in this collection.

Adato A, Lefèvre G, Delprat B, Michel V, Michalski N, Chardenoux S, Weil D, El-Amraoui A, Petit C. 2005a. Usherin, the defective protein in Usher syndrome type IIA, is likely to be a component of interstereocilia ankle links in the inner ear sensory cells. Hum Mol Genet 14: 3921-3932. doi:10.1093/hmg/ddi416

Adato A, Michel V, Kikkawa Y, Reiners J, Alagramam KN, Weil D, Yonekawa H, Wolfrum U, El-Amraoui A, Petit C. 2005b. Interactions in the network of Usher syndrome type 1 proteins. Hum Mol Genet 14: 347-356. doi:10.1093/hmg/ddi031

Ahmed ZM, Riazuddin S, Bernstein SL, Ahmed Z, Khan S, Griffith AJ, Morell RJ, Friedman TB, Riazuddin S, Wilcox ER. 2001. Mutations of the protocadherin gene PCDH15 cause Usher syndrome type 1F. Am J Hum Genet 69: 2534. doi:10.1086/321277

Ahmed ZM, Goodyear R, Riazuddin S, Lagziel A, Legan PK, Behra M, Burgess SM, Lilley KS, Wilcox ER, Riazuddin S, et al. 2006. The tip-link antigen, a protein associated with the transduction complex of sensory hair cells, is protocadherin-15. J Neurosci 26: 7022-7034. doi:10.1523/ jneurosci.1163-06.2006

Alagramam KN, Yuan H, Kuehn MH, Murcia CL, Wayne S, Srisailpathy CR, Lowry RB, Knaus R, Van Laer L, Bernier FP, et al. 2001. Mutations in the novel protocadherin PCDH15 cause Usher syndrome type 1F. Hum Mol Genet 10: 1709-1718. doi:10.1093/hmg/10.16.1709
Araya-Secchi R, Neel BL, Sotomayor M. 2016. An elastic element in the protocadherin-15 tip link of the inner ear. Nat Commun 7: 13458. doi:10.1038/ncomms13458

Assad JA, Shepherd GM, Corey DP. 1991. Tip-link integrity and mechanical transduction in vertebrate hair cells. Neuron 7: 985-994. doi:10.1016/0896-6273(91)90343-X

Avan P, Büki B, Petit C. 2013. Auditory distortions: Origins and functions. Physiol Rev 93: 1563-1619. doi:10.1152/ physrev.00029.2012

Bahloul A, Michel V, Hardelin JP, Nouaille S, Hoos S, Houdusse A, England P, Petit C. 2010. Cadherin-23, myosin VIIa and harmonin, encoded by Usher syndrome type I genes, form a ternary complex and interact with membrane phospholipids. Hum Mol Genet 19: 3557-3565. doi:10.1093/hmg/ddq271

Bahloul A, Pepermans E, Raynal B, Wolff N, Cordier F, England P, Nouaille S, Baron B, El-Amraoui A, Hardelin JP, et al. 2017. Conformational switch of harmonin, a submembrane scaffold protein of the hair cell mechanoelectrical transduction machinery. FEBS Lett 591: 22992310. doi:10.1002/1873-3468.12729

Bartolami S, Goodyear R, Richardson G. 1991. Appearance and distribution of the $275 \mathrm{kD}$ hair-cell antigen during development of the avian inner ear. J Comp Neurol 314: 777-788. doi:10.1002/cne.903140410

Belyantseva IA, Boger ET, Friedman TB. 2003. Myosin XVa localizes to the tips of inner ear sensory cell stereocilia and is essential for staircase formation of the hair bundle. Proc Natl Acad Sci 100: 13958-13963. doi:10.1073/ pnas. 2334417100

Beurg M, Fettiplace R. 2017. PIEZO2 as the anomalous mechanotransducer channel in auditory hair cells. J Physiol 595: 7039-7048. doi:10.1113/JP274996

Beurg M, Goldring AC, Ricci AJ, Fettiplace R. 2016. Development and localization of reverse-polarity mechanotransducer channels in cochlear hair cells. Proc Natl Acad Sci 113: 6767-6772. doi:10.1073/pnas.1601067113

Bitner-Glindzicz M, Lindley KJ, Rutland P, Blaydon D, Smith VV, Milla PJ, Hussain K, Furth-Lavi J, Cosgrove KE, Shepherd RM, et al. 2000. A recessive contiguous gene deletion causing infantile hyperinsulinism, enteropathy and deafness identifies the Usher type $1 \mathrm{C}$ gene. Nat Genet 26: 56-60. doi:10.1038/79178

Boeda B, El-Amraoui A, Bahloul A, Goodyear R, Daviet L, Blanchard S, Perfettini I, Fath KR, Shorte S, Reiners J, et al. 2002. Myosin VIIa, harmonin and cadherin 23, three Usher I gene products that cooperate to shape the sensory hair cell bundle. EMBO J 21: 6689-6699. doi:10.1093/ emboj/cdf689

Bolz H, von Brederlow B, Ramirez A, Bryda EC, Kutsche K, Nothwang HG, Seeliger M, del CSCM, Vila MC, Molina OP, et al. 2001. Mutation of $\mathrm{CDH} 23$, encoding a new member of the cadherin gene family, causes Usher syndrome type 1D. Nat Genet 27: 108-112. doi:10.1038/ 83667

Bork JM, Peters LM, Riazuddin S, Bernstein SL, Ahmed ZM, Ness SL, Polomeno R, Ramesh A, Schloss M, Srisailpathy $\mathrm{CR}$, et al. 2001. Usher syndrome $1 \mathrm{D}$ and nonsyndromic autosomal recessive deafness DFNB12 are caused by allelic mutations of the novel cadherin-like gene CDH23. Am J Hum Genet 68: 26-37. doi:10.1086/316954 
Caberlotto E, Michel V, Foucher I, Bahloul A, Goodyear RJ, Pepermans E, Michalski N, Perfettini I, Alegria-Prevot O, Chardenoux S, et al. 2011. Usher type $1 \mathrm{G}$ protein sans is a critical component of the tip-link complex, a structure controlling actin polymerization in stereocilia. Proc Natl Acad Sci 108: 5825-5830. doi:10.1073/pnas. 1017114108

Chen Q, Zou J, Shen Z, Zhang W, Yang J. 2014. Whirlin and PDZ domain-containing 7 (PDZD7) proteins are both required to form the quaternary protein complex associated with Usher syndrome type 2. J Biol Chem 289: 36070-36088. doi:10.1074/jbc.M114.610535

* Corey DP, Akyuz N, Holt JR. 2018. Function and dysfunction of TMC channels in inner ear hair cells. Cold Spring Harb Pespect Med doi:10.1101/cshperspect.a033506

Cosgrove D, Zallocchi M. 2014. Usher protein functions in hair cells and photoreceptors. Int J Biochem Cell Biol 46: 80-89. doi:10.1016/j.biocel.2013.11.001

Csukas SR, Rosenquist TH, Mulroy MJ. 1987. Connections between stereocilia in auditory hair cells of the alligator lizard. Hear Res 30: 147-155. doi:10.1016/0378-5955(87) 90132-8

* Cunningham CL, Müller U. 2018. Molecular structure of the hair cell mechanoelectrical transduction complex. Cold Spring Harb Pespect Med doi:10.1101/cshperspect. a033167

Delprat B, Michel V, Goodyear R, Yamasaki Y, Michalski N, El-Amraoui A, Perfettini I, Legrain P, Richardson G, Hardelin JP, et al. 2005. Myosin XVa and whirlin, two deafness gene products required for hair bundle growth, are located at the stereocilia tips and interact directly. Hum Mol Genet 14: 401-410. doi:10.1093/hmg/ddi036

Dionne G, Qiu X, Rapp M, Liang X, Zhao B, Peng G, Katsamba PS, Ahlsen G, Rubinstein R, Potter CS, et al. 2018. Mechanotransduction by PCDH15 relies on a novel cis-dimeric architecture. Neuron 99: 480-492.e5. doi: 10.1016/j.neuron.2018.07.006

Di Palma F, Pellegrino R, Noben-Trauth K. 2001. Genomic structure, alternative splice forms and normal and mutant alleles of cadherin 23 (Cdh23). Gene 281: 31-41. doi:10.1016/S0378-1119(01)00761-2

Ebermann I, Scholl HP, Charbel Issa P, Becirovic E, Lamprecht J, Jurklies B, Millán JM, Aller E, Mitter D, Bolz H. 2007. A novel gene for Usher syndrome type 2: Mutations in the long isoform of whirlin are associated with retinitis pigmentosa and sensorineural hearing loss. Hum Genet 121: 203-211. doi:10.1007/s00439-006-0304-0

Ebermann I, Phillips JB, Liebau MC, Koenekoop RK, Schermer B, Lopez I, Schafer E, Roux AF, Dafinger C, Bernd A, et al. 2010. PDZD7 is a modifier of retinal disease and a contributor to digenic Usher syndrome. J Clin Invest 120: 1812-1823. doi:10.1172/JCI39715

Ebrahim S, Avenarius MR, Grati M, Krey JF, Windsor AM, Sousa AD, Ballesteros A, Cui R, Millis BA, Salles FT, et al. 2016. Stereocilia-staircase spacing is influenced by myosin III motors and their cargos espin-1 and espin-like. Nat Commun 7: 10833. doi:10.1038/ncomms 10833

El-Amraoui A, Petit C. 2005. Usher I syndrome: Unravelling the mechanisms that underlie the cohesion of the growing hair bundle in inner ear sensory cells. J Cell Sci 118: 45934603. doi:10.1242/jcs.02636

Eudy JD, Weston MD, Yao S, Hoover DM, Rehm HL, MaEdmonds M, Yan D, Ahmad I, Cheng JJ, Ayuso C, et al.
1998. Mutation of a gene encoding a protein with extracellular matrix motifs in Usher syndrome type IIa. Science 280: 1753-1757. doi:10.1126/science.280.5370.1753

Flock A, Duvall AJ. 1965. The ultrastructure of the kinocilium of the sensory hair cells in the inner ear and the lateral line organs. J Cell Biol 25: 1-8.

Furness DN, Hackney CM. 1985. Cross-links between stereocilia in the guinea pig cochlea. Hear Res 18: 177-188. doi:10.1016/0378-5955(85)90010-3

Furness DN, Katori Y, Nirmal Kumar B, Hackney CM. 2008. The dimensions and structural attachments of tip links in mammalian cochlear hair cells and the effects of exposure to different levels of extracellular calcium. Neuroscience 154: 10-21. doi:10.1016/j.neuroscience.2008.02.010

Furuse M, Izumi Y. 2017. Molecular dissection of smooth septate junctions: Understanding their roles in arthropod physiology. Ann NY Acad Sci 1397: 17-24.

Giese APJ, Tang YQ, Sinha GP, Bowl MR, Goldring AC, Parker A, Freeman MJ, Brown SDM, Riazuddin S, Fettiplace R, et al. 2017. CIB2 interacts with TMC1 and TMC2 and is essential for mechanotransduction in auditory hair cells. Nat Commun 8: 43. doi:10.1038/s41467-01700061-1

Goodyear R, Richardson G. 1992. Distribution of the $275 \mathrm{kD}$ hair cell antigen and cell surface specialisations on auditory and vestibular hair bundles in the chicken inner ear. $J$ Comp Neurol 325: 243-256. doi:10.1002/cne.903250208

Goodyear R, Richardson G. 1999. The ankle-link antigen: An epitope sensitive to calcium chelation associated with the hair-cell surface and the calycal processes of photoreceptors. J Neurosci 19: 3761-3772. doi:10.1523/jneurosci.19-10-03761.1999

Goodyear RJ, Richardson GP. 2003. A novel antigen sensitive to calcium chelation that is associated with the tip links and kinocilial links of sensory hair bundles. J Neurosci 23: 4878-4887. doi:10.1523/jneurosci.23-1204878.2003

Goodyear RJ, Legan PK, Wright MB, Marcotti W, Oganesian A, Coats SA, Booth CJ, Kros CJ, Seifert RA, Bowen-Pope DF, et al. 2003. A receptor-like inositol lipid phosphatase is required for the maturation of developing cochlear hair bundles. J Neurosci 23: 9208-9219. doi:10.1523/ jneurosci.23-27-09208.2003

Goodyear RJ, Marcotti W, Kros CJ, Richardson GP. 2005. Development and properties of stereociliary link types in hair cells of the mouse cochlea. J Comp Neurol 485: 75-85. doi:10.1002/cne.20513

Goodyear RJ, Forge A, Legan PK, Richardson GP. 2010. Asymmetric distribution of cadherin 23 and protocadherin 15 in the kinocilial links of avian sensory hair cells. J Comp Neurol 518: 4288-4297. doi:10.1002/cne.22456

Goodyear RJ, Jones SM, Sharifi L, Forge A, Richardson GP. 2012. Hair bundle defects and loss of function in the vestibular end organs of mice lacking the receptor-like inositol lipid phosphatase PTPRQ. J Neurosci 32: 2762 2772. doi:10.1523/jneurosci.3635-11.2012

Grati M, Shin JB, Weston MD, Green J, Bhat MA, Gillespie PG, Kachar B. 2012. Localization of PDZD7 to the stereocilia ankle-link associates this scaffolding protein with the Usher syndrome protein network. J Neurosci 32: 1428814293. doi:10.1523/jneurosci.3071-12.2012 
Grillet N, Xiong W, Reynolds A, Kazmierczak P, Sato T, Lillo C, Dumont RA, Hintermann E, Sczaniecka A, Schwander $\mathrm{M}$, et al. 2009. Harmonin mutations cause mechanotransduction defects in cochlear hair cells. Neuron 62: 375 387. doi:10.1016/j.neuron.2009.04.006

Hillman DE. 1969. New ultrastructural findings regarding a vestibular ciliary apparatus and its possible functional significance. Brain Res 13: 407-412. doi:10.1016/00068993(69)90301-1

Hirono M, Denis CS, Richardson GP, Gillespie PG. 2004. Hair cells require phosphatidylinositol 4,5-bisphosphate for mechanical transduction and adaptation. Neuron 44: 309-320. doi:10.1016/j.neuron.2004.09.020

Holt JR, Gillespie SK, Provance DW, Shah K, Shokat KM, Corey DP, Mercer JA, Gillespie PG. 2002. A chemicalgenetic strategy implicates myosin-1c in adaptation by hair cells. Cell 108: 371-381. doi:10.1016/S0092-8674 (02)00629-3

Hu QX, Dong JH, Du HB, Zhang DL, Ren HZ, Ma ML, Cai Y, Zhao TC, Yin XL, Yu X, et al. 2014. Constitutive G $\alpha_{i}$ coupling activity of very large $\mathrm{G}$ protein-coupled receptor 1 (VLGR1) and its regulation by PDZD7 protein. J Bio Chem 289: 24215-24225. doi:10.1074/jbc.M114.549816

Hudspeth AJ, Jacobs R. 1979. Stereocilia mediate transduction in vertebrate hair cells (auditory system/cilium/vestibular system). Proc Natl Acad Sci 76: 1506-1509. doi:10.1073/pnas.76.3.1506

Indzhykulian AA, Stepanyan R, Nelina A, Spinelli KJ, Ahmed ZM, Belyantseva IA, Friedman TB, Barr-Gillespie PG, Frolenkov GI. 2013. Molecular remodeling of tip links underlies mechanosensory regeneration in auditory hair cells. PLoS Biol 11: e1001583. doi:10.1371/journal. pbio. 1001583

Jacobs RA, Hudspeth AJ. 1990. Ultrastructural correlates of mechanoelectrical transduction in hair cells of the bullfrog's internal ear. Cold Spring Harb Symp Quant Biol 55: 547-561. doi:10.1101/SQB.1990.055.01.053

Jaiganesh A, Narui Y, Araya-Secchi R, Sotomayor M. 2018. Beyond cell-cell adhesion: Sensational cadherins for hearing and balance. Cold Spring Harb Perspect Biol 10: a029280. doi:10.1101/cshperspect.a029280

Jones C, Roper VC, Foucher I, Qian D, Banizs B, Petit C, Yoder BK, Chen P. 2008. Ciliary proteins link basal body polarization to planar cell polarity regulation. Nat Genet 40: 69-77. doi:10.1038/ng.2007.54

Jovine L, Park J, Wassarman PM. 2002. Sequence similarity between stereocilin and otoancorin points to a unified mechanism for mechanotransduction in the mammalian inner ear. BMC Cell Biol 3: 28. doi:10.1186/1471-21213-28

Kachar B, Parakkal M, Kurc M, Zhao Y, Gillespie PG. 2000 High-resolution structure of hair-cell tip links. Proc Natl Acad Sci 97: 13336-13341. doi:10.1073/pnas.97.24.13336

Kazmierczak P, Sakaguchi H, Tokita J, Wilson-Kubalek EM, Milligan RA, Müller U, Kachar B. 2007. Cadherin 23 and protocadherin 15 interact to form tip-link filaments in sensory hair cells. Nature 449: 87-91. doi:10.1038/nature06091

Kindt KS, Finch G, Nicolson T. 2012. Kinocilia mediate mechanosensitivity in developing zebrafish hair cells. Dev Cell 23: 329-341. doi:10.1016/j.devcel.2012.05.022
Kitajiri S, Fukumoto K, Hata M, Sasaki H, Katsuno T, Nakagawa T, Ito J, Tsukita S, Tsukita S. 2004. Radixin deficiency causes deafness associated with progressive degeneration of cochlear stereocilia. J Cell Biol 166: 559-570. doi: $10.1083 /$ jcb. 200402007

Kremer H, van Wijk E, Märker T, Wolfrum U, Roepman R. 2006. Usher syndrome: Molecular links of pathogenesis, proteins and pathways. Hum Mol Genet 15 (Spec No 2): R262-R270. doi:10.1093/hmg/ddl205

* Krey JF, Barr-Gillespie PG. 2018. Molecular composition of vestibular hair bundles. Cold Spring Harb Pespect Med doi:10.1101/cshperspect.a033209

Küssel-Andermann P, El-Amraoui A, Safieddine S, Hardelin JP, Nouaille S, Camonis J, Petit C. 2000. Unconventional myosin VIIA is a novel A-kinase-anchoring protein. J Biol Chem 275: 29654-29659. doi:10.1074/jbc.M004393200

Lagziel A, Ahmed ZM, Schultz JM, Morell RJ, Belyantseva IA, Friedman TB. 2005. Spatiotemporal pattern and isoforms of cadherin 23 in wild type and waltzer mice during inner ear hair cell development. Dev Biol 280: 295-306. doi:10.1016/j.ydbio.2005.01.015

Lefevre G, Michel V, Weil D, Lepelletier L, Bizard E, Wolfrum U, Hardelin JP, Petit C. 2008. A core cochlear phenotype in USH1 mouse mutants implicates fibrous links of the hair bundle in its cohesion, orientation and differential growth. Development 135: 1427-1437. doi:10.1242/ dev.012922

Liu X, Bulgakov OV, Darrow KN, Pawlyk B, Adamian M, Liberman MC, Li T. 2007. Usherin is required for maintenance of retinal photoreceptors and normal development of cochlear hair cells. Proc Natl Acad Sci 104: 4413-4418. doi:10.1073/pnas.0610950104

Lukashkin AN, Legan PK, Weddell TD, Lukashkina VA, Goodyear RJ, Welstead LJ, Petit C, Russell IJ, Richardson GP. 2012. A mouse model for human deafness DFNB22 reveals that hearing impairment is due to a loss of inner hair cell stimulation. Proc Natl Acad Sci 109: $19351-$ 19356. doi:10.1073/pnas.1210159109

Mburu P, Mustapha M, Varela A, Weil D, El-Amraoui A, Holme RH, Rump A, Hardisty RE, Blanchard S, Coimbra RS, et al. 2003. Defects in whirlin, a PDZ domain molecule involved in stereocilia elongation, cause deafness in the whirler mouse and families with DFNB31. Nat Genet 34: 421-428. doi:10.1038/ng1208

McGee J, Goodyear RJ, McMillan DR, Stauffer EA, Holt JR, Locke KG, Birch DG, Legan PK, White PC, Walsh EJ, et al. 2006. The very large G-protein-coupled receptor VLGR1: A component of the ankle link complex required for the normal development of auditory hair bundles. $J$ Neurosci 26: 6543-6553. doi:10.1523/jneurosci.069306.2006

McMillan DR, White PC. 2004. Loss of the transmembrane and cytoplasmic domains of the very large G-proteincoupled receptor-1 (VLGR1 or Mass1) causes audiogenic seizures in mice. Mol Cell Neurosci 26: 322-329. doi:10.1016/j.mcn.2004.02.005

McMillan DR, Kayes-Wandover KM, Richardson JA, White PC. 2002. Very large G protein-coupled receptor-1, the largest known cell surface protein, is highly expressed in the developing central nervous system. J Biol Chem 277: 785-792. doi:10.1074/jbc.M108929200 
Michalski N, Michel V, Bahloul A, Lefevre G, Barral J, Yagi $\mathrm{H}$, Chardenoux S, Weil D, Martin P, Hardelin JP, et al. 2007. Molecular characterization of the ankle-link complex in cochlear hair cells and its role in the hair bundle functioning. J Neurosci 27: 6478-6488. doi:10.1523/ jneurosci.0342-07.2007

Michalski N, Michel V, Caberlotto E, Lefevre GM, van Aken AF, Tinevez JY, Bizard E, Houbron C, Weil D, Hardelin JP, et al. 2009. Harmonin-b, an actin-binding scaffold protein, is involved in the adaptation of mechanoelectrical transduction by sensory hair cells. Pflugers Arch 459: 115-130. doi:10.1007/s00424-009-0711-x

Michel V, Goodyear RJ, Weil D, Marcotti W, Perfettini I, Wolfrum U, Kros CJ, Richardson GP, Petit C. 2005. Cadherin 23 is a component of the transient lateral links in the developing hair bundles of cochlear sensory cells. Dev Biol 280: 281-294. doi:10.1016/j.ydbio.2005.01.014

* Montcouquiol M, Kelley MW. 2018. Development and patterning of the cochlea: From convergent extension to planar polarity. Cold Spring Harb Pespect Med doi:10.1101/ cshperspect.a033266

Montcouquiol M, Rachel RA, Lanford PJ, Copeland NG, Jenkins NA, Kelley MW. 2003. Identification of Vangl2 and Scrb1 as planar polarity genes in mammals. Nature 423: 173-177. doi:10.1038/nature01618

Montcouquiol M, Sans N, Huss D, Kach J, Dickman JD, Forge A, Rachel RA, Copeland NG, Jenkins NA, Bogani D, et al. 2006. Asymmetric localization of Vangl2 and Fz3 indicate novel mechanisms for planar cell polarity in mammals. J Neurosci 26: 5265-5275. doi:10.1523/jneurosci.4680-05.2006

Nagel G, Neugebauer DC, Schmidt B, Thurm U. 1991. Structures transmitting stimulatory forces to the sensory hairs of vestibular ampullae of frogs and fishes. Cell Tissue Res 265: 567-578.

Nayak G, Goodyear RJ, Legan PK, Noda M, Richardson GP. 2011. Evidence for multiple, developmentally regulated isoforms of Ptprq on hair cells of the inner ear. Dev Neurobiol 71: 129-141. doi:10.1002/dneu.20831

Neugebauer G, Thurm U. 1985. Interconnections between the stereovilli of the fish inner ear. Cell Tissue Res 240: 449-453.

Neugebauer DC, Thurm U. 1986. Surface charges influence the distances between vestibular stereovilli. Naturwissenschaften 73: 508-509. doi:10.1007/BF00367202

Neugebauer DC, Thurm U. 1986. Surface charges influence the distances between vestibular stereovilli. Naturwissenschaften 73: 508-509. doi:10.1007/BF00367202

Oganesian A, Poot M, Daum G, Coats SA, Wright MB, Seifert RA, Bowen-Pope DF. 2003. Protein tyrosine phosphatase RQ is a phosphatidylinositol phosphatase that can regulate cell survival and proliferation. Proc Nat Acad Sci 100: 7563-7568. doi:10.1073/pnas. 1336511100

Pan L, Zhang M. 2012. Structures of usher syndrome 1 proteins and their complexes. Physiology 27: 25-42. doi:10.1152/physiol.00037.2011

Pan L, Yan J, Wu L, Zhang M. 2009. Assembling stable hair cell tip link complex via multidentate interactions between harmonin and cadherin 23. Proc Natl Acad Sci 106: 5575-5580. doi:10.1073/pnas.0901819106

Pepermans E, Michel V, Goodyear R, Bonnet C, Abdi S, Dupont T, Gherbi S, Holder M, Makrelouf M, Hardelin
JP, et al. 2014. The CD2 isoform of protocadherin-15 is an essential component of the tip-link complex in mature auditory hair cells. EMBO Mol Med 6: 984-992. doi:10.15252/emmm.201403976

Pickles JO, Comis SD, Osborne MP. 1984. Cross-links between stereocilia in the guinea pig organ of Corti, and their possible relation to sensory transduction. Hear Res 15: 103-112. doi:10.1016/0378-5955(84)90041-8

Prieto JJ, Merchan JA. 1986. Tannic acid staining of the cell coat of the organ of Corti. Hear Res 24: 237-241. doi: 10.1016/0378-5955(86)90022-5

Reiners J, van Wijk E, Marker T, Zimmermann U, Jurgens K, te Brinke H, Overlack N, Roepman R, Knipper M, Kremer $\mathrm{H}$, et al. 2005. Scaffold protein harmonin (USH1C) provides molecular links between Usher syndrome type 1 and type 2. Hum Mol Genet 14: 3933-3943. doi: $10.1093 / \mathrm{hmg} / \mathrm{ddi} 417$

Reiners J, Nagel-Wolfrum K, Jurgens K, Marker T, Wolfrum U. 2006. Molecular basis of human Usher syndrome: Deciphering the meshes of the Usher protein network provides insights into the pathomechanisms of the Usher disease. Exp Eye Res 83: 97-119. doi:10.1016/j.exer.2005. 11.010

Richardson GP, Bartolami S, Russell IJ. 1990. Identification of a $275-\mathrm{kD}$ protein associated with the apical surfaces of sensory hair cells in the avian inner ear. J Cell Biol 110: 1055-1066. doi:10.1083/jcb.110.4.1055

Ross AJ, May-Simera H, Eichers ER, Kai M, Hill J, Jagger DJ, Leitch CC, Chapple JP, Munro PM, Fisher S, et al. 2005. Disruption of Bardet-Biedl syndrome ciliary proteins perturbs planar cell polarity in vertebrates. Nat Genet 37: 1135-1140. doi:10.1038/ng1644

Rüsch A, Thurm U. 1990. Spontaneous and electrically induced movements of ampullary kinocilia and stereovilli. Hear Res 48: 247-263. doi:10.1016/0378-5955(90) 90065-W

Sakaguchi H, Tokita J, Naoz M, Bowen-Pope D, Gov NS, Kachar B. 2008. Dynamic compartmentalization of protein tyrosine phosphatase receptor $\mathrm{Q}$ at the proximal end of stereocilia: Implication of myosin VI-based transport. Cell Motil Cytoskeleton 65: 528-538. doi:10.1002/ cm. 20275

Salles FT, Merritt RC Jr, Manor U, Dougherty GW, Sousa AD, Moore JE, Yengo CM, Dosé AC, Kachar B. 2009. Myosin IIIa boosts elongation of stereocilia by transporting espin 1 to the plus ends of actin filaments. Nat Cell Biol 11: 443-450. doi:10.1038/ncb1851

Salles FT, Andrade LR, Tanda S, Grati M, Plona KL, Gagnon LH, Johnson KR, Kachar B, Berryman MA. 2014. CLIC5 stabilizes membrane-actin filament linkages at the base of hair cell stereocilia in a molecular complex with radixin, taperin, and myosin VI. Cytoskeleton 71: 61-78. doi: $10.1002 / \mathrm{cm} .21159$

Sathyanarayana BK, Hahn Y, Patankar MS, Pastan I, Lee B. 2009. Mesothelin, stereocilin, and otoancorin are predicted to have superhelical structures with ARM-type repeats. BMC Struct Biol 9: 1. doi:10.1186/1472-6807-9-1

Schraders M, Oostrik J, Huygen PL, Strom TM, van Wijk E, Kunst HP, Hoefsloot LH, Cremers CW, Admiraal RJ, Kremer H. 2010. Mutations in PTPRQ are a cause of autosomal-recessive nonsyndromic hearing impairment 
DFNB84 and associated with vestibular dysfunction. $A m J$ Hum Genet 86: 604-610. doi:10.1016/j.ajhg.2010.02.015

Seifert RA, Coats SA, Oganesian A, Wright MB, Dishmon M, Booth CJ, Johnson RJ, Alpers CE, Bowen-Pope DF. 2003. PTPRQ is a novel phosphatidylinositol phosphatase that can be expressed as a cytoplasmic protein or as a subcellularly localized receptor-like protein. Exp Cell Res 287: 374-386. doi:10.1016/S0014-4827(03)00121-6

Self T, Sobe T, Copeland NG, Jenkins NA, Avraham KB, Steel KP. 1999. Role of myosin VI in the differentiation of cochlear hair cells. Dev Biol 214: 331-341. doi:10.1006/ dbio.1999.9424

* Sheffield AM, Smith RJH. 2018. The epidemiology of deafness. Cold Spring Harb Pespect Med doi:10.1101/cshperspect.a033258

Shin JB, Adams D, Paukert M, Siba M, Sidi S, Levin M, Gillespie PG, Grunder S. 2005. Xenopus TRPN1 (NOMPC) localizes to microtubule-based cilia in epithelial cells, including inner-ear hair cells. Proc Natl Acad Sci 102: 12572-12577. doi:10.1073/pnas.0502403102

Shin D, Lin ST, Fu YH, Ptacek LJ. 2013. Very large G proteincoupled receptor 1 regulates myelin-associated glycoprotein via Gos/Goq-mediated protein kinases A/C. Proc Natl Acad Sci 110: 19101-19106. doi:10.1073/pnas. 1318501110

Siemens J, Kazmierczak P, Reynolds A, Sticker M, Littlewood-Evans A, Muller U. 2002. The Usher syndrome proteins cadherin 23 and harmonin form a complex by means of PDZ-domain interactions. Proc Natl Acad Sci 99: 14946-14951. doi:10.1073/pnas.232579599

Siemens J, Lillo C, Dumont RA, Reynolds A, Williams DS, Gillespie PG, Müller U. 2004. Cadherin 23 is a component of the tip link in hair-cell stereocilia. Nature 428: 950955. doi:10.1038/nature02483

Sollner C, Rauch GJ, Siemens J, Geisler R, Schuster SC; the Tubingen 2000 Screen Consortium. 2004. Mutations in cadherin 23 affect tip links in zebrafish sensory hair cells. Nature 428: 955-959. doi:10.1038/nature02484

Sotomayor M, Corey DP, Schulten K. 2005. In search of the hair-cell gating spring elastic properties of ankyrin and cadherin repeats. Structure 13: 669-682. doi:10.1016/j. str.2005.03.001

Sotomayor M, Weihofen WA, Gaudet R, Corey DP. 2010. Structural determinants of cadherin-23 function in hearing and deafness. Neuron 66: 85-100. doi:10.1016/j.neuron.2010.03.028

Sotomayor M, Weihofen WA, Gaudet R, Corey DP. 2012. Structure of a force-conveying cadherin bond essential for inner-ear mechanotransduction. Nature 492: 128-132. doi:10.1038/nature11590

Stauffer EA, Scarborough JD, Hirono M, Miller ED, Shah K, Mercer JA, Holt JR, Gillespie PG. 2005. Fast adaptation in vestibular hair cells requires myosin-1c activity. Neuron 47: 541-553. doi:10.1016/j.neuron.2005.07.024

Stepanyan R, Frolenkov GI. 2009. Fast adaptation and $\mathrm{Ca}^{2+}$ sensitivity of the mechanotransducer require myosinXVa in inner but not outer cochlear hair cells. J Neurosci 29: 4023-4034. doi:10.1523/jneurosci.4566-08.2009

Tilney LG, Tilney MS, Cotanche DA. 1988. Actin filaments, stereocilia, and hair cells of the bird cochlea. V: How the staircase pattern of stereociliary lengths is generated. J Cell Biol 106: 355-365. doi:10.1083/jcb.106.2.355
Tsuprun V, Santi P. 1998. Structure of outer hair cell stereocilia links in the chinchilla. J Neurocytol 27: 517-528. doi:10.1023/A:1006903926571

Tsuprun V, Santi P. 2002. Structure of outer hair cell stereocilia side and attachment links in the chinchilla cochlea. J Histochem Cytochem 50: 493-502. doi: 10.1177/002215540205000406

Tsuprun V, Schachern PA, Cureoglu S, Paparella M. 2003. Structure of the stereocilia side links and morphology of auditory hair bundle in relation to noise exposure in the chinchilla. J Neurocytol 32: 1117-1128. doi:10.1023/B: NEUR.0000021906.08847.d2

Tsuprun V, Goodyear RJ, Richardson GP. 2004. The structure of tip links and kinocilial links in avian sensory hair bundles. Biophys J 87: 4106-4112. doi:10.1529/biophysj.104.049031

van Wijk E, Pennings RJ, te Brinke $\mathrm{H}$, Claassen A, Yntema HG, Hoefsloot LH, Cremers FP, Cremers CW, Kremer H. 2004. Identification of 51 novel exons of the Usher syndrome type $2 \mathrm{~A}$ (USH2A) gene that encode multiple conserved functional domains and that are mutated in patients with Usher syndrome type II. Am J Hum Genet 74: 738-744. doi:10.1086/383096

van Wijk E, van der Zwaag B, Peters T, Zimmermann U, Te Brinke H, Kersten FF, Marker T, Aller E, Hoefsloot LH, Cremers CW, et al. 2006. The DFNB31 gene product whirlin connects to the Usher protein network in the cochlea and retina by direct association with USH2A and VLGR1. Hum Mol Genet 15: 751-765. doi:10.1093/ hmg/ddi490

Vélez-Ortega AC, Freeman MJ, Indzhykulian AA, Grossheim JM, Frolenkov GI. 2017. Mechanotransduction current is essential for stability of the transducing stereocilia in mammalian auditory hair cells. eLife 6: e24661.

Verpy E, Leibovici M, Zwaenepoel I, Liu XZ, Gal A, Salem N, Mansour A, Blanchard S, Kobayashi I, Keats BJ, et al. 2000. A defect in harmonin, a PDZ domain-containing protein expressed in the inner ear sensory hair cells, underlies Usher syndrome type 1C. Nat Genet 26: 51-55. doi:10.1038/79171

Verpy E, Masmoudi S, Zwaenepoel I, Leibovici M, Hutchin TP, Del Castillo I, Nouaille S, Blanchard S, Laine S, Popot JL, et al. 2001. Mutations in a new gene encoding a protein of the hair bundle cause nonsyndromic deafness at the DFNB16 locus. Nat Genet 29: 345-349. doi:10.1038/ ng726

Verpy E, Weil D, Leibovici M, Goodyear RJ, Hamard G, Houdon C, Lefevre GM, Hardelin JP, Richardson GP, Avan P, et al. 2008. Stereocilin-deficient mice reveal the origin of cochlear waveform distortions. Nature 456: 255-258. doi:10.1038/nature07380

Verpy E, Leibovici M, Michalski N, Goodyear RJ, Houdon C, Weil D, Richardson GP, Petit C. 2011. Stereocilin connects outer hair cell stereocilia to one another and to the tectorial membrane. J Comp Neurol 519: 194-210. doi:10.1002/cne.22509

Vona B, Hofrichter MA, Neuner C, Schroder J, Gehrig A, Hennermann JB, Kraus F, Shehata-Dieler W, Klopocki E, Nanda I, et al. 2015. DFNB16 is a frequent cause of congenital hearing impairment: Implementation of STRC mutation analysis in routine diagnostics. Clin Genet 87: 49-55. doi:10.1111/cge.12332 
G.P. Richardson and C. Petit

Webb SW, Grillet N, Andrade LR, Xiong W, Swarthout L, Della Santina CC, Kachar B, Muller U. 2011. Regulation of PCDH15 function in mechanosensory hair cells by alternative splicing of the cytoplasmic domain. Development 138: 1607-1617. doi:10.1242/dev.060061

Weil D, Blanchard S, Kaplan J, Guilford P, Gibson F, Walsh J, Mburu P, Varela A, Levilliers J, Weston MD, et al. 1995. Defective myosin VIIA gene responsible for Usher syndrome type IB. Nature 374: 60-61. doi:10.1038/ 374060a0

Weston MD, Luijendijk MW, Humphrey KD, Möller C, Kimberling WJ. 2004. Mutations in the VLGR1 gene implicate G-protein signaling in the pathogenesis of Usher syndrome type II. Am J Hum Genet 74: 357-366. doi:10.1086/381685

Wu Z, Grillet N, Zhao B, Cunningham C, Harkins-Perry S, Coste B, Ranade S, Zebarjadi N, Beurg M, Fettiplace R, et al. 2017. Mechanosensory hair cells express two molecularly distinct mechanotransduction channels. Nat Neurosci 20: 24-33. doi:10.1038/nn.4449

Yagi H, Tokano H, Maeda M, Takabayashi T, Nagano T, Kiyama H, Fujieda S, Kitamura K, Sato M. 2007. Vlgr1 is required for proper stereocilia maturation of cochlear hair cells. Genes Cells 12: 235-250. doi:10.1111/j.1365 2443.2007.01046.x

Zeng WZ, Grillet N, Dewey JB, Trouillet A, Krey JF, BarrGillespie PG, Oghalai JS, Muller U. 2016. Neuroplastin isoform Np55 is expressed in the stereocilia of outer hair cells and required for normal outer hair cell function. $J$ Neurosci 36: 9201-9216. doi:10.1523/jneurosci.009316.2016

Zhao H, Williams DE, Shin JB, Brugger B, Gillespie PG. 2012. Large membrane domains in hair bundles specify spatially constricted radixin activation. J Neurosci 32: 4600-4609. doi:10.1523/jneurosci.6184-11.2012

Zou J, Chen Q, Almishaal A, Mathur PD, Zheng T, Tian C, Zheng QY, Yang J. 2017. The roles of USH1 proteins and PDZ domain-containing USH proteins in USH2 complex integrity in cochlear hair cells. Hum Mol Genet 26: 624-636.

Zwaenepoel I, Mustapha M, Leibovici M, Goodyear R, Liu XZ, Nouaille S, Nance WE, Kaanan M, Avraham KB, Tekaia F, et al. 2002. Otoancorin, an inner ear protein restricted to the interface between the apical surface of sensory epithelia and their overlying acellular gels, is defective in autosomal recessive deafness DFNB22. Proc Natl Acad Sci 99: 6240-6245. 


\section{$\& \mathrm{CSH} \&$ Cold Spring Harbor

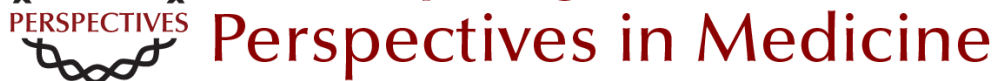

\section{Hair-Bundle Links: Genetics as the Gateway to Function}

Guy P. Richardson and Christine Petit

Cold Spring Harb Perspect Med 2019; doi: 10.1101/cshperspect.a033142 originally published online January 7, 2019

\section{Subject Collection Function and Dysfunction of the Cochlea}

Hidden Hearing Loss: A Disorder with Multiple Etiologies and Mechanisms

David C. Kohrman, Guoqiang Wan, Luis Cassinotti, et al.

Hair Cell Afferent Synapses: Function and Dysfunction

Stuart L. Johnson, Saaid Safieddine, Mirna Mustapha, et al.

Active Biomechanics of Sensory Hair Bundles Dolores Bozovic

The Tectorial Membrane: Mechanical Properties and Functions

Jonathan B. Sellon, Roozbeh Ghaffari and Dennis M. Freeman

The Epidemiology of Deafness Abraham M. Sheffield and Richard J.H. Smith

Toward the Optical Cochlear Implant Tobias Dombrowski, Vladan Rankovic and Tobias Moser

Outer Hair Cells and Electromotility Jonathan Ashmore

Interactions between Macrophages and the Sensory Cells of the Inner Ear Mark E. Warchol
Development and Patterning of the Cochlea: From Convergent Extension to Planar Polarity Mireille Montcouquiol and Matthew W. Kelley

Hair-Bundle Links: Genetics as the Gateway to Function

Guy P. Richardson and Christine Petit

Aminoglycoside- and Cisplatin-Induced

Ototoxicity: Mechanisms and Otoprotective

Strategies

Corné J. Kros and Peter S. Steyger

Function and Dysfunction of TMC Channels in Inner Ear Hair Cells

David P. Corey, Nurunisa Akyuz and Jeffrey R. Holt

Cochlear Gene Therapy

Lawrence Lustig and Omar Akil

Age-Related Hearing Loss

Michael R. Bowl and Sally J. Dawson

Inner Ear Connexin Channels: Roles in Development and Maintenance of Cochlear Function

Fabio Mammano

A Functional Perspective on the Evolution of the Cochlea Christine Köppl and Geoffrey A. Manley

For additional articles in this collection, see http://perspectivesinmedicine.cshlp.org/cgi/collection/ 